Sırnak Üniversitesi

Illahiyat Fakültesi Dergisi

Cilt: 11, Sayı: 24, Haziran 2020

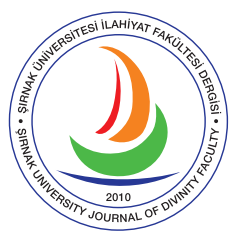

Şırnak University Journal of Divinity Faculty

Vol.: 11, Issue: 24, June 2020

e-ISSN 2667-6575

\title{
Mubahın Şer'î Hüküm Olup Olmaması ile İlgili Yaklaşımlar ve Bunun Mubahın Sınırlandırılması ile İlişkilendirilmesi
} Approaches Regarding Whether or Not Mubah (Legal Freedom) Has Religious

Provision and Its Relation to the Limitation of Mubah

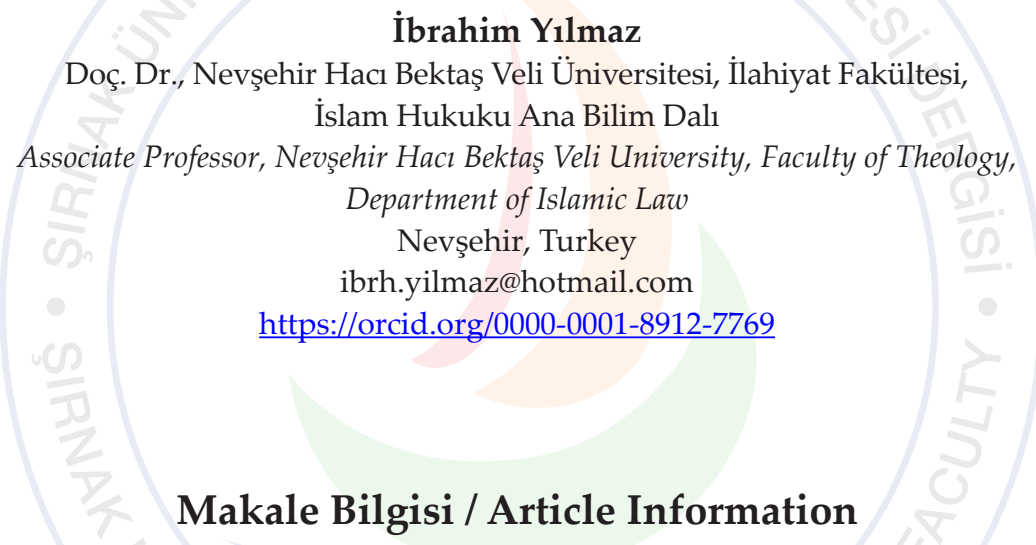

Makale Türü / Article Types: Araştırma Makalesi / Research Article

Geliş Tarihi / Received: 2 Mart / March 2020

Kabul Tarihi / Accepted: 5 Mayıs / May 2020

Yayın Tarihi / Published: 15 Haziran / June 2020

Cilt / Volume: 11 Sayı / Issue: 24 Sayfa / Pages: 206-239

Atıf / Cite as: Yılmaz, İbrahim. "Mubahın Şer'î Hüküm Olup Olmaması ile İlgili Yaklaşımlar ve Bunun Mubahın Sınırlandırılması ile İlişkilendirilmesi [Approaches Regarding Whether or Not Mubah (Legal Freedom) Has Religious Provision and Its Relation to the Limitation of Mubah]". Şırnak Üniversitesi İlahiyat Fakültesi Dergisi - Şırnak University Journal of Divinity Faculty 11/24 (June 2020), 206-239. https://doi.org/10.35415/sirnakifd.697482

Etik Beyanı / Ethics Declaration: Bu makalede bilimsel araştırma ve yayın etiği ilkelerine riayet edilmiştir. Makale etik izin gerektirmeyen bir çalışma olup en az iki hakem tarafından incelenmiş ve intihal içermediği teyit edilmiştir./ In this article, the principles of scientific research and publication ethics are respected. The article is a study that does not require ethical permission. It has been reviewed by at least two referees and was confirmed that it did not contain plagiarism.

Copyright ( Published by Şırnak Üniversitesi, İlahiyat Fakültesi / Şırnak, Türkiye (Şırnak University, Faculty of Divinity, Şırnak, 73000 Turkey). 


\title{
Öz
}

İslâm hukuk metodolojisinde hükmün tanımı ile ilgili biri kaynağını, diğeri muhatabını esas alan iki temel yaklaşım vardır. Kaynağını esas alan yaklaşıma göre hüküm Şâri'in hitabı, muhatabını esas alan yaklaşıma göre ise hüküm Şâri'in hitabının sonucudur. Her iki yaklaşıma göre de hükmün tanımında biri "talep/iktizâ", diğeri "tahyîr/muhayyerlik" olmak üzere iki temel kavram yer almaktadır. Hükmün tanımında yer alan "talep/iktizâ" kavramı; farz/vacip, mendup, mekruh ve haram gibi şer'î hükümleri içermektedir. "Tahyîr" ise mubah olan hükümleri ifade etmektedir. Klasik dönem İslâm hukuku metodolojisinde mubahın mahiyetiyle ilgili; "teklîfî hüküm olup olmaması", "şer'î hüküm olup olmaması", "emredilmiş olup olmaması" ve "talep içerip içermemesi" gibi birçok konu tartışılmıştır. Hiç şüphesiz bu konulardan en önemlisi, "mubahın şer'î hüküm olup olmaması" hakkında cumhur ile Mu'tezilî âlimler arasında geçen tartısmadır. Cumhur, mubahın teklîfí/şer'î hükümlerden biri olduğunu söylemektedir. Buna mukabil Mu'tezilî âlimlerden Abu'l-Kasim al-Belhî el-Kâ'bî (öl. 319/911) ve onun taraftarları ise mubahın şer'î bir hüküm olmadığını söylemektedirler. Diğer taraftan Mubahın şer'î hüküm olup olmaması meselesi, "kamu otoritesinin mubahı/cevazı sınırlandırma yetkisi" bağlamında son dönemlerde de tartısılmaya devam etmektedir. Nitekim Osmanlı'nın son dönemlerinde Mansurizâde Said (1864-1923), kamu otoritesinin mubahı sınırlandırması bağlamında "cevazın ahkâm-ı şer' iyyeden olmadığına dair" makaleler yazmıştır. Günümüz İslâm hukukçularından bazıları da Mansurizâde'nin görüşünü haklı bulmaktadır. Ancak kanaatimizce bu iki konu, yani mubahın şer'î hüküm olması ile mubahın kamu otoritesi tarafından sınırlandırılması arasında doğrudan bir ilişki bulunmamaktadır.

Anahtar Kelimeler: İslam Hukuku, Mubah, Şer'î Hüküm, Mubahın Sınırlandırılması. Kamu Otoritesi.

\begin{abstract}
In Islamic Law Methodology, there are two basic approaches related to the definition of the religious provision, one based on its source and the other based on its addressee / interlocutor. According to the former approach, religious provision is addressing / appeal of the Shari (Lawmaker) and according to the latter approach, religious provision is result of addressing of the Shari (Lawmaker). According to both approaches, there are two basic concepts in the definition of the provision, one of which is "talab / iktidha" and the other is "tahyir / being muhayyar". The concept of "talab / iktidha" in the definition of the provision; It includes religious provisions such as fard / wajib, mandub, makruh and haram. "Tahyir" refers to the religious provisions that are permissible (mubah / legal freedom). In the classical period Islamic law methodology (usûl al-fiqh), about the nature of mubah; many issues such as "whether there is a proposal", "whether there is a religious provision", "whether it is ordered" and "whether it contains a request" are discussed. Undoubtedly, the most important of these issues is the debate among majority of Islamic lawyers and the Mu'tezilite scholars about "whether there is a religious provision". Majority of Islamic jurists say that mubah is one of religious provisions. On the other hand, Mu'tezilite scholar Abu'1-Qasim al-Balkhi el-Ka'bi (d. 319/911) and his supporters say that mubah is not a religious provision. On the other hand, the issue of whether or not mubah is a religious provision still being discussed recently in the context of the public authority's limitation of mubah. As a matter of fact, in the last period of the Ottoman Empire, Mansurizada Said (1864-1923) wrote articles about "that mubah is not one of the religious provision" in the context of public authority's limitation of mubah. Some of today's Islamic lawyers justify this view of Mansurizada. However, in our opinion, there is no direct relationship between these two issues, namely, the fact that mubah is the religious provision and the limitation of mubah by the public authority.
\end{abstract}

Keywords: Islamic Law, Mubah (Legal Freedom), Religious Provisions, Limitation of Mubah Limitation of Mubah, Public Authority. 


\section{Extended Abstract}

In Islamic Law Methodology, there are two basic approaches related to the definition of the religious provision, one based on its source and the other based on its addressee / interlocutor. According to the former approach, religious provision is addressing / appeal of the Shari (Lawmaker) and according to the latter approach, religious provision is result of addressing of the Shari (Lawmaker). According to both approaches, there are two basic concepts in the definition of the provision, one of which is "talab / iktidha" and the other is "tahyir / being muhayyar". The concept of "talab / iktidha" in the definition of the provision; It includes religious provisions such as fard / wajib, mandub, makruh and haram. "Tahyir" refers to the religious provisions that are permissible (mubah / legal freedom).

In the classical period Islamic law methodology (usûl al-fiqh), about the nature of mubah; many issues such as "whether there is a proposal", "whether there is a religious provision", "whether it is ordered" and "whether it contains a request" are discussed. Undoubtedly, the most important of these issues is the debate among majority of Islamic lawyers and the Mu'tezilite scholars about "whether there is a religious provision". Majority of Islamic jurists say that mubah is one of religious provisions. On the other hand, Mu'tezilite scholar Abu'l-Qasim al-Balkhi el-Ka'bi (d. 319/911) and his supporters say that mubah is not a religious provision. One of the most important figures in the history of Islamic law, Abu Hamid Muhammad al-Gazzali (d. 505/1111) draws attention to the difficulty of understanding the issue by saying "this is a subject with depth and requires investigation" regarding this issue that is being discussed among majority of Islamic jurists and Mu'tezilite scholars. As can be understood from the opinions and explanations of the parties concerned, the essence of the debate between $\mathrm{Ka}$ 'bi and some of the Mutezilite scholars and majority of Islamic jurists, without making a distinction before or after religious declaration, "Whether or not sin should be made in the conduct or abandonment of a behavior is mentally fixed".

Mutezilite scholars act on the principle of "something should be originally permissible (istishab / asli ibaha)" and they are based on whether or not a sin / objection should be done or not without making a distinction before and after religious reporting. Therefore, when the issue is viewed from this perspective, they say that mubah cannot be evaluated in the ruling category. Because, according to Ka'bi and his supporters, unless there is a prohibitive or imperative religious provision about it, the position of something that is fixed before the religious declaration (within the scope of the preliminary ibaha) is fixed after the religious declaration, whether or not it is fixed by the address of Shari, it continues exactly. Accordingly, it is not possible to take part in the religious provision as something that is known to be done or not that there is no sin by reason.

On the other hand, jumhur (majority of Islamic jurists) says that the unreserved sin will be fixed only with the address of Shari, in other words, with religious declaration. Accordingly, it is a sin to do or leave something, but can be known after religious reporting. Hence, a behavior that is fixed by religious addressing is in the category of the religious provision. In this context, mubah is a religious provision because it is fixed with addressing of Shari. On the other hand, according to the statements of Fakhraddin al-Razi (d. 606/1209) and Bihari (d. 1119/1707), in the final analysis, the original ibaha is also within the scope of the religious provision, in which the Shari is silent or there is no mandatory or prohibitive religious provision.

On the other hand, the issue of whether or not mubah is a religious provision still 
being discussed recently in the context of the public authority's limitation of mubah. As a matter of fact, in the last period of the Ottoman Empire, Mansurizada Said (1864-1923) wrote articles about "that mubah is not one of the religious provision" in the context of public authority's limitation of mubah. Some of today's Islamic lawyers justify this view of Mansurizada. However, in our opinion, there is no direct relationship between these two issues, namely, the fact that mubah is the religious provision and the limitation of mubah by the public authority.

It is possible to list the conclusions we have reached in this study on the subject of "Approaches to Whether or not Mubah is a Judgment in Islamic Legal Methodology / theory of religious provisions" as follows;

1) In classical Islamic law methodology / theory of religious provisions, "tahyir", which is included in the definition of the religious provisions, it expresses the legal free fields, that is, the mubah.

2) As a term of fiqh, mubah, without any condemnation ( $\sin$ ) and praise (reward), it is legal free fields that Shari frees on whether to make it or not.

3) In classical Islamic law methodology, there are two basic approaches regarding whether or not mubah is a religious provision, one belonging to the majority of Islamic jurists and the other to Mu'tazilite scholar Ka'bi and his followers.

4) Majority of Islamic jurists are based on the addressing of Shari in the peace of the religious provisions and says that the addressing (nass/verses) encompasses all life events and in this context, mubah is included within the scope of religious provisions.

5) Mutazilite scholars, on the other hand, determine whether Shari (lawmaker) has sinned on the issue while determining the religious provisions of a matter. According to this, they say that mubah is not within the scope of religious provisions because it does not contain any sin if it is done or abandoned. Among today's Islamic lawyers, Wahba al-Zuhayli also justifies this approach of Mutezilite scholars.

6) Gazzali, who said that whether or not mubah is within the scope of religious provisions, is a matter that has depth and requires investigation, made the acts that fall under the scope of mubah in a triple division and made evaluations that in some situations, Mutezilite scholars might be right.

7) Mansurizada Said, one of the most recent jurist thinkers of the Ottoman Empire, and some jurists such as Ali Bardakoğlu and Abdullah Kahraman, from today's Islamic jurists, agree with the view of the Mutazilite scholars and say that it is more appropriate to ensure that mubah is not covered by religious provisions.

8) On the other hand, Islamic jurists like H. Yunus Apaydın and Mehmet Erdogan, from today's Islamic jurists, say that the mubah is within the scope of the religious provisions, therefore the opinion of jumhur (majority of scholars) is more accurate.

9) On the other hand, Mansurizada Said and some Islamic lawyers who agree with his opinion have tried to establish a relationship between whether mubah is among the religious provisions and the authority of the head of state (public authority) to limit the mubah. 10) However, it is possible to say that there is no need to establish a direct relationship between whether mubah is a religious provision and the authority of the head of state (public authority) to limit the mubah, considering that the mubah can take different religious provisions according to the conditions, that is, the benefit and the damage.

11) As a matter of fact, according to the classical doctrine of fiqh, it is accepted that the head of the state (public authority) has the right and authority to limit mubah in the public interest when the conditions and needs are necessary. 


\section{Gíriș}

İslâm hukuk metodolojisinde (hüküm teorisinde) hükmün; biri kaynağını, diğeri muhatabını esas alan iki farklı tanımı yapılmıştır. Tanımda kaynağını esas alan mütekellimin/Şâfiî usulcülere göre hüküm, Allah'ın, iktizâ veya tahyîr ya da vaz' yönüyle mükelleflerin fiillerine ilişkin hitabıdır. ${ }^{1}$ Tanımda muhatabı (mükellefin fiilini) esas alan fukahaya/Hanefilere göre ise hüküm, Allah'ın, iktizâ veya tahyîr ya da vaz' yönüyle mükelleflerin fiillerine ilişkin hitâbının sonucudur. ${ }^{2}$

Usulcülerin çoğunluğuna göre hüküm, "teklîfî" ve "vaz'î"”3 olmak üzere iki kısma ayrılmaktadır. ${ }^{4}$ Usulcülerin istılahında -mutlak olarak zikredildiğinde- şer'î hüküm ile kastedilen ise teklîfî hükümlerdir. ${ }^{5}$ Usulcü-

1 Bk. Ebû Hâmid Muhammed el-Gazzâlî, el-Müstasfâ min ilmi'l-usûl, thk. Hamza b. Züheyr Hafız (Medine: ty.), 1/177; Fahreddin er-Râzî, el-Mahsûl fi ilmi l-usûl, thk. Cabir Feyyyâd elAlvânî (Beyrut: Müessesetü'r-Risâle, ty.), 1/89; Ebu'l-Hasan Ali b. Muhammed Se yfeddin el-Âmidî, el-ïhkâm fì usûli'l-ahkâm, tlk. Abdurrazzak Afifi (Riyad: Dâru's-Samîî, 2003), 1/131; Muhammed b. Ali b. Muhammed eş-Şevkânî, İrşâdül-fühûl ilâ tahkîki ilmi'l-usûl, thk. Ebu Mus'ab Muhammed Saîd el-Bedrî (Beyrût: Müessesetü'1-kütübi's-sikâfiyye, 1992), 23.

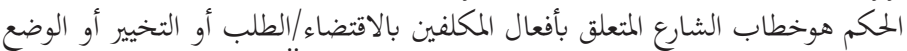

2 Sa'duddin Mes'ûd b. Ömer et-Teftazânî, Şerhu't-Telvîh (Beyrut: Dâru'l-kütübi'l-ilmiyye, ty.), 1/22-23; Molla Hüsrev, Mir'âtül-usûl (İstanbul: Dersaâdet, 1321), 276.

الحكم هوأثرخطاب الشارع المتعلق بأفعال المكلفين بالاقتضاء/الطلب أو التخيير أو الوضع

3 Vaz'î hüküm, Şâri'in bir şeyi teklîfî hüküm için sebep, şart, illet, alâmet, rükûn ve mâni' kılmasıdır. Bk. Fahrettin Atar, Fıkı Usûlü (İstanbul: MÜİF Yayınları, 1996), 133.

${ }^{4}$ Şer'î hükmün taksimi ile ilgili bk. Ebû İshak İbrahim b. Mûsâ eş-Şâtıbî, el-Muvâfakât fí usûli'ş-şeriâ, nşr./tlk. Abdullah Dıraz (Beyrut: Dâru'l-marife, 1975), 1/109; Teftazânî, Şerhu't-Telvîh, 1/24; Ebû Abdillah Bedruddin Muhammed b. Bahadır eş-Şâfiî ez-Zerkeşî, el-Bahru 7-muhît fì usûli'l-fikh, nşr. Abdulkadir Abdullah el-Ânî ve Ömer Süleyman el-Aşkar (Kuveyt: Vizâratü'l-evkâfi'ş-şuûniyye, 1992), 1/127; Abdülvahhab el-Hallâf, İlmü usûli'l-fikh (İstanbul: el-Mektebetü'l-İslâmiyye, 1984), 113-114; Atar, Fikıh Usûulü, 116.

5 Hükmün tanımı ve çeşitleri hakkında geniş bilgi için bk. Muhammed Ebü'l-Feth elBeyânûnî, "Hüküm (Fıkıh)", Türkiye Diyanet Vakfı İslâm Ansiklopedisi (İstanbul: TDV 
lerin teklîfî hüküm için yaptıkları tanım -vaz'î (الوضع) kaydı dışında- şer'î hükmün kaynağını veya muhatabını esas alarak yaptıkları tanımın aynısıdır. ${ }^{6}$ Son dönem İslâm hukukçuları ise genellikle mütekellimîn usulcülerin hüküm tanımını esas alarak teklîfî hükmü, "Şâri'in mükelleften bir işi yapmasını veya yapmamasını istemesi (el-iktizâlet-taleb) ya da onu bir işi yapıp yapmama arasında muhayyer bırakması (tahyîr)"7 şeklinde tanımlamışlardır.

Hükmün tanımında geçen "iktizâltaleb" kavramı, bir şeyin yapılması$\mathrm{n}$ veya yapılmamasını istemek anlamına gelmektedir. Yapılması istenilen fiiller; farz/vâcip veya mendup olarak, yapılmaması istenilen fiiller ise haram veya mekruh olarak isimlendirilmiştir. "Tahyîr" ise bir işin yapılması veya yapılmaması hususunda mükellefi muhayyer/serbest bırakmaktır. Mükellefin eşit seviyede muhayyer bırakıldığı fiillere ise mubah denilmektedir. ${ }^{8}$ Buna göre İslam hüküm teorisinde cumhura göre beş teklîfî hükümden biri de "mubah" terimi ile ifade edilen hukukî serbest alanlar olmaktadır."

Sözlükte "açık olmak, açığa çıkarmak" anlamındaki "b-v-h" kökünden türetilen ebâha fiilinin ism-i mefulü olan "mubah" kelimesi; "serbest bırakılmış, izin verilmiş, müsaade edilmiş, yasaklığı kaldırılmış" gibi anlamlara gelmektedir. "Ebâha" fiilinin mastarı olan "ibâha" kelimesi ise sözlükte; "açığa çıkarmak, açıklamak; serbest bırakmak, izin vermek, helâl kılmak, câiz kılmak; genişlik sağlamak" gibi anlamlara gelmektedir. ${ }^{10}$ Teknik bir terim olarak ise ibâha, "muhayyer kılmak yani, kişinin bir fiili dilediği gibi yapmasına izin vermek", mubah da "iki tarafı yani yapılması ve yapılmaması eşit olan şey"11

Yayınları, 1998), 18/466-468; Davut İltaş, Fıkıh Usulünde Mütekellimîn Yönteminin Delâlet Anlayışı (İstanbul: İSAM, 2011), 103-127.

6 Teklifi hükmün tanımı ile ilgili bk. Zekiyyüddin Şaban, İslâm Hukuk İlminin Esasları (Usûlü̈l-fikıh), çev. İbrahim Kâfi Dönmez (Ankara: Türkiye Diyanet Vakfı Yayınlar,1 2015), 227, 230.

7 Bk. Hallâf, İlmü usûli'l-fikh, 114; Muhammed Ebû Zehra, Usûlü̈l-fikh (İstanbul: Tebliğ Yay., ty.), 27; Şaban, Usûlül-fikh, 227, 230; Atar, Fikıh Usûlü, 117; Beyânûnî, “Hüküm”, 467.

8 Bk. Gazzâlî, el-Müstasfâ, 1/210-211; Râzî, el-Mahsûl, 1/89; Hallâf, İlmü usûlil-fikh, 118; Atar, Fikı Usûlü, 116.

9 İslâm hüküm teorisinde "mubah" konusu hakkında geniş bilgi için bk. M. Sellâm Medkûr, Nazariyyetu'l-ibâha inde'-usuliyyin vel-fukâhâ (Kahire: Dâru'n-Nehdati'l-Arabiyye, 1984), 32 vd.; el-Mevsûatül-fikhiyye, "İbâha" (Kuveyt: Vizâratü'l-evkâf ve'ş-şuûni'l-islâmiyye, 1983), 1/132-135; İbrahim Kâfi Dönmez, "Mubah", Türkiye Diyanet Vakfi İslâm Ansiklopedisi (İstanbul: TDV Yayınları, 2005), 30/341-345; Emrullah Dumlu, "Hukukî Serbest Alan: Mubah (Klasik Yaklaşım ve Şâtıbî Örneği)", İslâm Hukuku Araştırmaları Dergisi 22 (Ekim 2013), 157-186.

10 İbn Manzûr, "bvh", Lisânü7-Arab (Kahire Dâru'l-meârif, 1984), 1/384; Medkûr, Nazariyetü'ibâha, 31-32; Dönmez, "Mubah", 30/341.

${ }^{11}$ Cürcânî, et-Ta'rifât, "ibâha" ve "mubah" (Beyrut: Dârü'l-Kütübi'l-İlmiyye, 1983), 8, 196; Ömer Nasuhi Bilmen, Hukuk-ı İslâmiyye ve Istılahât-ı Fıkhiyye Kâmûsu (İstanbul: Bilmen Yay., 1985), 1/33; Medkûr, Nazariyetül-ibâha, 32; Mehmet Erdoğan, "İbâha" ve "Mübâh", 
anlamına gelmektedir. Bir fıkıh usulü terimi olarak mubahın birçok tanımı yapılmıştır. ${ }^{12}$ Ancak bu tanımlar; "herhangi bir zemm (kınama) ve medh (övgü) olmaksızın Şâri'in mükellefi yapıp yapmamakta muhayyer bıraktığ 1 fiil"13 anlaminda birleşmektedir.

Diğer taraftan İslâm hukukunda "mubah" kategorisinde yer alan hükümlerin/fiillerin, biri "tikel (cüz'î/özel)" diğeri "tümel (küllî/genel)" olmak üzere iki yönü bulunmaktadır. ${ }^{14}$ Buna göre tikel açıdan mubah, yapılması veya yapılmaması mükellef açısından iki tarafı eşit olan konumu ifade etmektedir. Tümel açıdan ise mubah, dinen korunması zorunlu olan beş temel esastan (zarûrât-i hamse) ${ }^{15}$ biriyle ilgili olması, başkalarının hakkını ve kamu yararını ilgilendirmesi, dinen yapılması (vâcip-mendup) veya terk edilmesi (haram-mekruh) istenilen bir fiile vesile olması (yani kullanılma gaye ve sonucuna itibar edilmesi) gibi haricî ve ârızî bazı sebeplerden dolayı farklı hükümler de alabilmektedir. ${ }^{16}$ Buna göre tümel açıdan mubah şartlara ve ihtiyaçlara göre -yapılması veya terkedilmesi yönünde- farklı hükümler de alabilen "değişken" bir konumu ifade etmektedir. ${ }^{17}$ Buna göre herhangi bir şart ve kayıt olmaksızın İslâm hukukunda bir fiilin mutlak olarak mubah olduğunu söylemek mümkün değildir. ${ }^{18}$

Dolayısıyla tümel açıdan bakıldığında, kamu otoritesinin -emretme veya yasaklama ya da kullanılmasını bazı kayıtlara bağlama şeklindemubahı sınırlandırması söz konusu olabilmektedir. Nitekim İslâm hukuk tarihinde erken dönemlerden itibaren "mubahın sınırlandırılması düşüncesi" İslâm hukukçularının ve devlet başkanlarının gündeminde olan bir konudur. Bundan dolayıdır ki; "Umûr-i câizede veliyyü'l-emr'in selâhiyeti ka-

Fikıh ve Hukuk Terimleri Sözlüğ̈̈ (İstanbul: Rağbet Yayınları, 1998), 171, 309.

${ }^{12}$ Mubahın tanımı için bk. Cüveynî, el-Burhân fì usûlil-fikh, thk. Abdulazim Muhammed ed-Dîb (Katar: h. 1399), 1/313; İbn Hazm, el-ìhkâm fì usûlil-ahkâm, thk. Muhammed Şakir (Beyrut Dâru'l-âfâki'l-cedîde, ty.), 1/44; Âmidî, el-îhkâm 1/165-166; Molla Hüsrev, Mirât, 278; Şevkânî, İrşâdül-fuhûl, 24.

${ }^{13}$ Bk. Hallâf, İlmü usûlil-fikh, 130; Abdülkerim Zeydan, el-Vecîz fî usîlil-fikh (Beyrut: Müessesetü'r-Risâle, 2011), 38; Şaban, Usûlül-fikh, 253.

${ }^{14}$ Şâtıbî, el-Muvâfakât, 1/130, 142.

${ }^{15}$ Bu beş temel maksat, İslâm hukukunda "zarûrât-1 hams" veya "zarûrât-1 külliye" olarak bilinen "dinin, aklın, malın, nefsin/canın ve neslin/nesebin" korunmasıdır. Bk. Şâtıbî, elMuvâfakât, 2/8-9; Ebû Zehra, Usûlül-fikh, 366-369; Zeydan, el-Vecîz, 300.

${ }^{16}$ Bk. Karâfî, el-Furûk fi Envâri'l-burûk fi envâi'l-furuk (Beyrut: Dâru'l-kütübi'l-ilmiyye, 1998), 2/61 (Fark: 58); Şâtıbî, el-Muvâfakât, 1/130, 142, 147, 313-314; 2/204. Ayrıca bk. Zerkeşî, elBahru 7-muhît, 1/275.

${ }^{17}$ Şâtıbî, el-Muvâfakât, 1/142, 147; Zerkeşî, el-Bahru'-muhît, 1/275. Ayrıca krş. Ebu Bekir Ahmet b. Ali er-Râzî el-Cessâs, el-Fusûl fil-usûl, thk. Uceyl Casim en-Nemşi (Kuveyt: 1994), 2/248; 4/70-71.

${ }^{18}$ Krş. Şâtıbî, el-Muvâfakât, 1/130, 142, 147. 
idesi müsellemattandır./Mubah (câiz) olan bir konuda devlet başkanının tasarruf yetkisine sahip olması herkesin kabul ettiği bir kaidedir." ${ }^{19}$ fıkıh kaidesi İslâm hukukçuları tarafından genel kabul görmüştür. ${ }^{20}$ Mubahın sınırlandırılması ile kastedilen ise şudur:

"Şartların ve ihtiyaçların gerekli kılması halinde zararın giderilmesi veya kamu yararının gerçekleşmesi gayesi ile yerine göre mubah ile amel edilmesinin askiya alınarak (durdurularak/yasaklanarak) veya mubah ile amel edilmesinin zorunlu hale getirilerek (vacip kılınarak/emrederek) bu konuda mükellefin seçim hakkının kaldırılmasıdır." ${ }^{21}$

Diğer taraftan klasik dönem fikıh usulü eserlerinde mubahın mahiyetiyle ilgili; "teklîfî hüküm olup olmaması", "şer'î hüküm olup olmaması", "emredilmiş olup olmaması" ve "talep içerip içermemesi" gibi birçok konu üzerinde durulmuştur. ${ }^{22}$ Ancak bu konuların, fikıh usulünün mahiyeti ve konusuyla doğrudan bir ilişkisi bulunmamaktadır. ${ }^{23}$ Nitekim Şâtıbî (öl. 790/1388), "ibahanın/mubahın teklîfî hüküm olup olmaması" veya "şer'î hüküm olup olmaması" gibi konuların usul kitaplarında yer almaması gerektiğini söylemektedir. ${ }^{24}$

Klasik fikıh usulü doktrininde, "mubahın şer'î hüküm olup olmaması" meselesi ile ilgili biri cumhura diğeri Mu'tezili âlimlerden Abu'l-Kasim alBelhî el-Kâ‘bî (öl. 319/911) ve onun taraftarlarına ait olmak üzere iki temel yaklaşım bulunmaktadır. Klasik dönem fikıh usulü kitaplarında tartışılan "mubahın şer'î hüküm olup olmamasi ${ }^{25}$ meselesi, "kamu otoritesinin muba-

${ }^{19}$ Bk. Aydın, M. Akif, İslâm-Osmanlı Aile Hukuku (Esbâb-ı Mûcibe Lâyihası/Nikâh-ı Mükreh) (İstanbul: MÜİFV Yayınları, 1985), 276.

20 İslâm hukukunda kamu otoritesinin mubahı (hukukî serbest alanı) sınırlandırma hak ve yetkisi ile ilgili bk. Muhammed Seyyid Bey, Fıkıh Usulü (Giriş), Yay. Haz: Hasan Karayiğit (İstanbul: Düşün Yayınları, 2010), 104-155; Mansurizâde Saîd, "Cevâzın Ahkâm-1 Şer'iyyeden Olmadığına Dâir", İslâm Mecmuası 1/10 (İstanbul 1330), 295-303; Medkûr, Nazariyyetu'-ibâha, 317-369; Beşir el-Mekkî Abdüllâvî, Sultatü veliyyil-emr fi takyîdil-mubâh (Beyrut: Dâru Mektebeti'l-Maârif, 2011). Konuyla ilgili ayrıca bk. Mecelle, md. 1192, 1197, $1200,1254$.

${ }^{21}$ Muhammed Fethî Dirînî, Hasâisü't-teşrîi'l-islâmî fi's-siyaseti ve'l-hükm (Beyrut: Müessesetü'rrisâle, 2013), 262 (2 nolu dipnot). Ayrıca bk. Muhammed Ebû Zehra, el-Cerîme (Kahire: Dâru'-fikri'l-Arabî, 1986), 282; Mustafa Ahmed ez-Zerkâ, el-Medhalül-fikhiyyül-âmm/elFikhu I-İslâmî fi sevbihi'l-cedîd (Dimeşk: Dâru'l-Fikr, 1968), 1/195.

22 Örnek olarak bk. Gazzâlî, el-Müstasfâ, 1/243-247; Âmidî, el-İhkâm, 1/166-169; Zerkeşî, elBahru '-muhît, 1/277-283; Sübkî, Raf'ü'-Hâcib, 2/5-9.

${ }^{23}$ Bk. Şaban, Usûlï̈l-fikh, 40-41.

${ }^{24}$ Bk. Şâtıbî, el-Muvâfakât, 1/43.

${ }^{25}$ Konuyla ilgili bk. Cüveynî, el-Burhân, 1/294-295; Gazzâlî, el-Müstasfâ, 1/245 vd.; Âmidî, el-İhkâm, 1/166; Zerkeşî, el-Bahru '-muhît, 1/277-278; Karâfî, Şerhu tenkîhu'-fusûl fi ihtisâri'Mahsûli fi'l-usûll (Beyrut: Dâru'l-fikr, 2004), 62-63. Ayrıca bk. Ahmed Husarî, Nazariyyetülhükm ve mesâdirü't-teşrî fì usûli'l-fikhil-İslâmî (Beyrut: Dârü'l-Kitâbi'l-Arabi, 1986), 37, 70; 
hı/cevazı sınırlandırma yetkisi" bağlamında son dönemlerde de tartışılmaya devam eden konularından biridir. Nitekim Osmanlı'nın son dönemlerinde Mansurizâde Said (1864-1923) ve İsmail Hakkı İzmirli (1869-1946) gibi dönemin önde gelen bazı ilim adamları kamu otoritesini mubahı/cevazı sınırlama yetkisi bağlamında "cevâzın ahkâm-1 şer'iyyeden olup olmadığına dair" makaleler yazmışlardır. ${ }^{26}$ Günümüzde yapılan bazı çalışmalarda da mubahın/ cevazın ahkâm-1 şer' iyyeden olup olmadığı ile ilgili görüşlere yer verilmiştir. ${ }^{27}$

\section{KLASİK FIKIH USÛLÜ DOKTRININNDE MUBAHIN ŞER'Î HÜKÜM OLUP OLMAMASI İLE İLGILI YAKLAŞIMLAR}

\subsection{Konuyla İlgili Görüşler}

\subsubsection{Cumhurun Yaklaşımı: Mubahın Şer'î Hüküm Olduğu Görüşü}

Klasik fıkıh usulü doktrininde usulcülerin çoğunluğu mubahın şer'î hükümlerden olduğu konusunda ittifak etmişlerdir..$^{28}$ Mubahın şer î hüküm olduğunu söyleyen cumhur, kendilerinin şer'î hüküm olarak kabul ettikleri ibahanın, şer'îldinî bildirim sonrası Şâri'in hitabı ile sabit olan ibaha olduğunu, Kâ'bî'nin şer'î hüküm olarak kabul etmediği ibahanın ise şer'̂̂/dinî bildirim öncesi sabit olan aslî ibaha (veya dini bildirim sonrasinda hakkında nass olmayan asli ibaha) olduğunu söylemektedirler. ${ }^{29}$ Dolayısıyla cumhur, Şâri'in hitabı ile sabit olmasından dolayı mubahın da şer'i hüküm olduğunu söylemektedir. ${ }^{30}$ Fahreddin er-Râzî (öl. 606/1210) ve Seyfeddin el-Âmidî (öl. 631/1233) gibi usulcüler, Ka'bî ile cumhur arasındaki ihtilafın lafzî olduğunu söylemekle birlikte cumhurun görüşünün isabetli olduğu şeklinde değerlendirmelerde bulunmaktadırlar. Konuyla ilgili Râzî'nin değerlendirmesi şöyledir:

Medkûr, Nazariyyetül-ibâha, 24; Dönmez, "Mubah", 30/341.

26 Örnek olarak bk. Mansurizâde Saîd, "Cevâzın Ahkâm-1 Şer'iyyeden Olmadığına Dâir", 295-303; İsmail Hakkı İzmirli, "Cevâzın Ahkâm-1 Şeriattan Olup Olmaması Hakkındaki Nizâ' Nizâ-i Lafzîdir", Sebilü'r-Reşad [Sırat-ı Müstakim] 12/303 (İstanbul, 19 Haziran 1330), 296-301.

${ }^{27}$ Örnek olarak bk. Ali Bardakoğlu, “Câiz”, Türkiye Diyanet Vakfi İslâm Ansiklopedisi (İstanbul: TDV Yayınları, 1993), 7/27. Ayrıca bk. Ekrem Koç, İslâm Hukuk İlminde Cevaz Kavramı (İstanbul: Marmara Üniversitesi, Sosyal Bilimler Ensitüsü, Yüksek Lisans Tezi, 2008), 30-34.

${ }^{28}$ Gazzâlî, el-Müstasfâ, 1/245; Amidî, el-íhkâm, 1/166. Ayrıca bk. M. Sellâm Medkûr, Mebâhisü̈ 7hükm ınde'l-usûliyyîn (Kahire: Dâru'n-nehdati'l-arabiyye, 1959), 109; Vehbe Zühaylî, Usulülfikhi'-islâmî (Dımeşk: Dâru'l-fikr, 1986), 1/88.

29 Âmidî, el-ïhkâm, 1/166; Medkûr, Nazariyyetü 7-ibâha, 25; Dönmez, “Mubah”, 30/341.

${ }^{30}$ Ebû Ayyâş Muhammed Abdül'alî b. Nizamüddin Bahrululûm el-Leknevî Ensârî, Fevâtihu'r-rahamût bi şerhi Müsellemi's-sübût, tsh. Abdullah Mahmud Muhammed Ömer (Beyrut: Dârul'l-kütübi'l-ilmiyye, 2002), 1/91. 
“Gerçek şu ki taraflar arasındaki hilaf lafzîdir. Çünkü bir şeyin mubah olması üç şekilde sabit olabilir. Birincisi, şeriatın, "isterseniz yapınız, isterseniz terk ediniz" şeklindeki sarih hitabı ile mükellefi muhayyer bırakmasıdır. İkincisi, şer'î nasların bir fiilin yapılmasında ve terk edilmesinde sakıncanın (harec) olmadığını" bildirmesidir. Üçüncüsü ise, Şâri'in sükût ettiği, yapılması ve terk edilmesi konusunda herhangi bir nassın varid olmadığı şeylerdir ki icma ile mükellef bu konuda muhayyerdir. Arzettiğimiz bu deliller sınırsız olarak tüm fiilleri kapsamaktadır. Dolayısıyla “şer'î hüküm” ile kastedilen şer'î/dinî bildirim sonrası için geçerlidir derseniz, gerçek böyle değildir. Çünkü bir şeyin mubah olması -şer'î/dinî bildirim öncesi ve sonrası diye bir ayırım olmaksızınonun mahiyetinin şeraite uygun olmasıdır. Şayet "şer'î hüküm" ile kasdedilen şer'î nasların onu onaylaması derseniz, bu da gerçeği yansıtmamaktadır. Çünkü bir şeyin mubah olması -yukarıda saymış olduğumuz- üç yoldan biri ile sabit olmaktadır. Buna göre her ne şekilde sabit olursa olsun Şâri'in hitabı buna delâlet etmektedir ve ibaha/mubah şer'î bir hüküm olmaktadır."31

Yukarıdaki ifadelerden de anlaşılacağı üzere Râzî, "taraflar arasındaki ihtilaf lafzîdir" demekle birlikte, cumhurun görüşünü destekleyen yorumlar yapmakta ve şer'î/dinî bildirim sonrasında her ne şekilde sabit olursa olsun mubahın şer'î hüküm kapsamında yer aldığını söylemektedir. Konuyla ilgili Âmidî'nin değerlendirmesi ise şöyledir:

“Yapılması veya terk edilmesi günah olmayan bir fiilin şer'î ibaha olmamasını biz de inkâr etmiyoruz. Çünkü şer'î ibaha, Şâri'in muhayyerlik içeren hitabıdır. Bu ise şer'î/dinî bildirim öncesinde sabit değildir. Bu ikisi arasındaki fark ise gizli değildir. Buna göre bizim şer'î hüküm olarak kabul ettiğimiz şer'î ibaha, Ka'bî'nin nefyettiği ibaha değildir." 32

Âmidî'nin yukarıdaki açıklamasından hem Mutezile'nin hem de cumhurun görüşünün haklı olduğu anlaşılmaktadır. Çünkü iki taraf, konuya farklı açılardan bakmaktadır. Buna göre ister şer'î bildirim öncesi olsun ister şer'î/dinî bildirim sonrası olsun Şâri'in hitabı ile sabit olmayan mubah şer'î bir hüküm olmamaktadır. Dolayısıyla Âmidî'ye göre, nass ile sabit olan şer'î ibaha şer'î bir hüküm kabul edilirken, nass ile sabit olmayan aslî baha şer'î bir hüküm olmamaktadır. Ancak usulcüler arasında aslî ibahanın şer'î hüküm olduğu konusunda farklı yorumlar da vardır. Nitekim Râzî̀ye göre aslî ibaha şer'î hükümdür. Muhibbüllah b. Abdüşşekûr el-Bihârî (öl. 1119/1707) de Müsellemü's-sübût'ta; "İbahay-ı aslîye de şer'î hükümdendir. Çünkü bir şeyin yapılması ve terk edilmesinin günah/sakınca (harec) olduğuna dair hakkında şer'î

${ }^{31}$ Râzî, el-Mahsûl, 2/213-214.

32 Âmidî, el-ïhkâm, 1/166. 
bir dayanağın bulunmaması bu şeyin Şâri' tarafindan muhayyer bırakıldı̆̆ına şer'î bir dayanaktır. ${ }^{\prime \prime 3}$ diyerek aslî ibahanın da şer'î hüküm kapsamında yer aldığını ifade etmektedir. ${ }^{34}$

Sonuç olarak cumhura göre bir meselenin "şer'î hüküm" olarak nitelenmesi talep ile yani vacip, mendup, haram ve mekruh ile olabileceği gibi tahyîr ile de olabilmektedir. Tahyîr ile sabit olan şer'î hükümler ise mubahlardır. Mubah ise Şâri'in hitabı ile sabit olabileceği gibi (şer'î ibaha) Şâri'in sükût etmesi (aslî ibaha) ile de sabit olabilmektedir. Nitekim Râzî (öl. 606/1210) ve İbn Abdüşşekûr el-Bihârî (öl. 1119/1707) gibi usulcülerin yukarıda naklettiğimiz ifadelerine göre Şâri'in sükût ettiği (meskûtün anh) muhayyerlik içeren aslî ibaha da Şâri' in hitabı ile mubah kılmayı (tahyîr) içermekte ve Şâri'in hitabı ile sabit olan şer'î bir hüküm olmaktadır.

\subsubsection{Ka'bî'nin Yaklaşımı: Mubahın Şer'î Hüküm Olmadığı Görüşü}

Klasik fıkıh usulü kitaplarında mubahın şerî̀ bir hüküm olmadığ 1 düşüncesi Mu'tezilî kelamcı ve usulcü Ebu'l-Kâsım el-Belhî el-Kâ'bî (öl. 319/911) ve onun taraftarlarına nispet edilmektedir..$^{35}$ Ka'bî'ye atfen aktarılan bu görüş ve değerlendirmelerden bazıları esas itibariyle "mubahın şer'î hükümden olup olmaması" ile ilgili olmayıp, "mubahın emredilmiş olması" veya "mubahın talep içerip içermemesi" konularıyla ilgilidir. Ancak Ka'bî ve diğer Mu'tezilî âlimlere nispet edilen görüşler, klasik fıkıh usulü kitaplarında genellikle "mubahın şer'î hükümden olup olmaması" başlığı altında verilmektedir.

\footnotetext{
${ }^{33}$ Muhibbüllah b. Abdüşşekûr el-Bihârî, Müsellemü's-sübût (Fevâtihu'r-rahamût bi şerhi Müsellemi's-sübût ile birlikte), tsh. Abdullah Mahmud Muhammed Ömer (Beyrut: Dârul'1-kütübi'l-ilmiyye, 2002), 1/91. Ayrıca bk. Râzî, el-Mahsûl, 2/213-214. Müsellemü'ssübût şerhinde aslî ibahanın da şer'î ibaha kapsamında yer aldığı ile ilgili şu ifadeler yer almaktadır (Ensâri, Fevâtihu'r-rahamût, 1/91):

(الإباحة حكم شرعى لأنه خطاب الشرع تخييرا) والخطاب هو الحكم الشرعى (والإباحة الأصلية نوع منه)

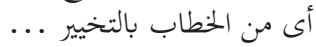

${ }^{34}$ Kıyası reddederek bunun yerine "aslî ibaha" ile amel edilmesi gerektiğini söyleyenlere cevap verirken Serahsî (öl. 483/1090-?), hakkında yasaklamanın olmadığı yerde bir şeyin mubah olmasının dayanağının, "Eşyada asıl olan mubahlıktır" kaidesi değil; "Allah yeryüzündeki her şeyi sizin için yarattı" (el-Bakara, 2/29) ayetinin olduğunu söylemektedir. Bk. Serahsî, Usûlü̈'-s-Serahsî, thk. Ebu'l-vefa el-Afğanî (Beyrut: Dâru'l-Ktübi'l-ilmiyye, 1993), 2/120. Serahsî'nin bu yaklaşımına göre aslî ibaha dolaylı olarak şer'î ibaha içinde yer almaktadır.

${ }^{35}$ Bu konuyla ilgili Mutezilenin görüşleri için bk. Cüveynî, el-Burhân, 1/294-295; Gazzâlî, elMüstasfâ, 1/245; Zerkeşî, el-Bahru 7-muhît, 1/277-278; Zühaylî, Usûlüll-fikh, 1/88.
} 
Gazzâlî́nin (öl. 505/1111) verdiği bilgiye göre Mu'tezilî âlimler açısından mubahlık şunu ifade etmektedir:

“Şer' in/Şâri'in bir şeyi mubah kılmasının anlamı; Şer'in/Şâri' in bir şeyin hükmünü değiştirmeksizin sem'i/şer'î bildirim öncesindeki hali üzere bırakmasıdır. Dolaysıyla haram olduğu veya vacip olduğu sabit olmayan bir şey aslî nefy üzere kalır ki buna da mubah (aslî ibaha) denir." 36

Mubahın şer'î hüküm olup olmamasında, "şer'î/sem'î delilin, yani Şâri'in hitabının varlığı ve yokluğu" ile "istishâb" kaidesinden, yani "eşyada asıl olan mubahlıktır" ilkesinden hareket eden Kâ'bî'ye göre mubahlıkta asıl olan, "bir şeyin yapılması veya terk edilmesinde günahın/sakıncanın (harec) olmaması"dır. Bu durum ise şer'î bildirimden önce sabit olduğu gibi -hakkında emredici veya yasaklayıcı bir hitap olmaması halinde- şer'î/dinî bildirim sonrasında da aynen devam etmektedir. Dolay1sıyla, hakkında nass olsun veya olmasın, -yapılması veya terk edilmesinde günahın olmaması bağlamında- şer'î/dinî bildirim öncesinde olduğu gibi sonrasında da şer'î hüküm kategorisinde yer alan mubah diye bir hüküm söz konusu değildir. ${ }^{37}$

Mubahın şer'î bir hüküm olmaması ile ilgili Ka'bî'nin bir diğer yaklaşımı ise şöyledir: "Her mubah bir mahzurun (haramın) terkidir. Mahzurun terk edilmesi ise vâciptir. Buna göre kendisi ile haramın terk edildiği mubah da vâcip olmaktadır. Dolayısılyla şeriatta mubah diye bir hüküm yoktur. ${ }^{\prime 38}$ Bu ifadeler mubahın şer'î hüküm olup olmamasından ziyade mubahın emredilmiş olup olmaması ile ilgilidir. Ka'bî'ye nispet edilen bu görüşe göre mubah emredilmiş olmaktadır. Dolayısıyla bir fiilin yapılması veya yapılmaması istenildiğine göre şeriatta "mubah" diye bir hüküm bulunmamaktadır. Son dönem İslâm hukukçularından Ebu Zehra (öl. 1974), Ka'bî'nin mubahı şer'î hükümden kabul etmemesi ile ilgili şu görüşleri aktarmaktadır:

"Şeriatta mükellefin yapıp yapmamakta muhayyer bırakıldığı mubah diye şer'î bir hüküm yoktur. Çünkü fiillerin yapılması Şâri' tarafından ya istenmiştir veya yasaklanmıştır. Dolayısıyla Şâri'in nazarında yapılması ve yapılmaması eşit olan bir fiil yoktur. Çünkü mükellefin yaptığı bir fiil ya kendisine zarar verir veya fayda verir. Bir fiilde zarar veya fayda olduğuna göre bu fiilin yapılması veya yapılmaması eşit olamaz. Şâri', faydası daha çok olan

${ }^{36}$ Gazzâlî, el-Müstasfâ, 1/245.

${ }^{37}$ Bk. Gazzâlî, el-Müstasfâ, 1/245; Râzî, el-Mahsûl, 2/213; Âmidî, el-İhkâm, 1/166; Karâfî, Şerhu Tenkîhül-fusûl, 62; Ebû Zehra, Usûlül-fikh, 48; Hudarî, Usûl, 55; Zühaylî, Usûlüll'-fikh, 1/88; Husarî, Nazariyyetül-hükm, 93; Dönmez, "Mubah", 30/341.

${ }^{38}$ Cüveynî, el-Burhân, 1/294; Gazzâlî, el-Müstasfâ, 1/241; Şâtıbî, el-Muvâfakât, 1/124-125; Medkûr, Mebâhisül-hükm, 109. 
fiilin yapılmasını ister, zararı daha çok olan fiili ise yasaklar. Dolayısıyla bir fiilin Şâri'in nazarında yapılıp yapılmaması eşit olamaz. Buna göre bir şeyin, övgü veya kınamayı gerektirmeyen iki tarafı eşit mubah bir fiil/hüküm olması mümkün değildir. Örneğin insanın kendisini telef etmemek için hayatını sürdürecek miktarda bir şeyler yemesi istenmektedir. Yine aynı şekilde insanın kendisini telef etmeye sevkedecek bir şeyi yemeyi terk etmesi de istenmektedir. İşte bu örnekte olduğu gibi mubah olarak vasıflandırılan her fiilin, ya faydalı veya zararlı tarafı daha ağır basmakta ve mutlaka bir tarafı tercih edilmektedir. Bundan dolayıdır ki mubah şerî bir hüküm değildir." ${ }^{39}$

Ebu Zehra, Ka'bî'nin mubahı şer'î hükümden kabul etmemesi ile ilgili ise şu değerlendirmeyi yapmaktadır:

“Ka'bî'ye göre şer'î hükümler kişinin niyetine tabidir. Buna göre mükellefin yaptığ 1 her bir fiilin özel bir maksadı vardır. Kişi bir fiili ya sevap işleme maksadı ile veya cezadan kaçınma maksadı ile yapar. Kişinin niyeti hayır ise karşılığında sevap, niyeti şer ise karşılığında günah vardır. Şâri' in mükellefin fiillerini kabul veya reddetmesi mükellefin niyet ve maksadına bağlıdır. Dolayısıyla bir fiilden güdülen maksada göre onun şer'î hükmü ya talep olur veya kaçınma olur." 40

Ka'bî̀ye nispet edilen bu görüşe göre mubah, kullanma amacı ve sonucuna göre tümel açıdan değerlendirilmektedir. Dolayısıyla tikel açıdan iki tarafı eşit olan bir fiil tümel açıdan farklı hüküm almakta, konuyla ilgili meselenin hükmü de mubah olmaktan çıkmaktadır. Nitekim Ebu Zehra da Ka'bî'nin görüşüne bu açıdan bakarak şu değerlendirmeyi yapmaktadır:

“Ka'bî'nin bu görüşünün mubah olan bir fiilin uygulamadaki karşılığı aç1sından bir bakıma kısmen haklılık payı vardır. Şöyle ki yemek cüz'î açıdan mubah olmakla birlikte vakıada kişinin hayatını devam ettirmesi için yemesi matluptur. Ancak kişinin matlup olan şeyler içerisinden seçim hakkı vardır. İşte bu yönü ile bir fiil cüz'î açıdan mubah olmaktadır." ${ }^{41}$

Ka'bî'nin yaklaşımını akla yetki verme ve alan açma çabası olarak değerlendiren günümüz İslâm hukukçularından H. Yunus Apaydın da Ka'bî'nin görüşü ile ilgili şu değerlendirmeyi yapmaktadır:

“Mu'tezilî kelamcı ve usulcülerden Ka’bî (öl. 319/931) mubahın, yapma ve yapmama sıkıntısını kaldırmak anlamını taşıdığını, bu anlamın da sem'den (yani Şari'in bildirimde bulunmasından) önce sabit olduğunu ve Şer'in bir

\footnotetext{
39 Ebû Zehra, Usûlül-fikh, 48. Ayrıca bk. Husarî, Nazariyyetül-hükm, 93.

${ }^{40}$ Ebû Zehra, Usûlü̈l-fikh, 48-49. Ayrıca bk. Medkûr, Mebâhisül-hükm, 108.

${ }^{41}$ Ebû Zehra, Usûlül-fikh, 49.
} 
şeyi mubah kılmasının, o şeyin hükmünü hiç degiştirmeden, -sem'in varid olmasından- önce nasıl ise o hal üzere bırakması anlamını taşıdığını gerekçe göstererek mubahın şer'i bir hüküm kategorisi olarak değerlendirilemeyeceğini iddia eder. Ka'bî'nin (ve taraftarlarının) bu yaklaşımında akla bir yetki tanıma ve alan açma çabası olduğu gözden kaçmamaktadır. Esasında Hanefiler dışındaki usulcülerin büyük çoğunluğunun "istishâbı" bir delil kabul etmesinin arkasında bir yandan kıyas ve benzeri metodları sınırlandırma düşüncesi, bir yandan da akla bir tür yetki verme ve alan açma düşüncesinin bulunup bulunmadığı araştırılmaya değer bir husustur." ${ }^{42}$

Yukarıda naklettiğimiz görüş ve açıklamalardan anlaşılacağı üzere Ka'bî, şer'î hüküm olup olmaması açısından mubahı cumhurdan farklı değerlendirmekte ve aslî ibaha ilkesini esas alarak bir fiile günahın terettüp etmemesinden hareketle mubahı şer'î hüküm kapsamında görmemektedir.

\subsection{Değerlendirme}

Mubahın şer'î hüküm olup olmaması meselesi, klasik fıkıh usulü kitaplarında bazı mu'tezilî usulcüler ile cumhur arasında ihtilaf edilen usul konularının başında gelmektedir. İslâm hukuk tarihinin önemli isimlerinden Ebû Hâmid Muhammed el-Gazzâlî (öl. 505/1111), cumhur ile Mu'tezilî âlimler arasında ihtilaf edilen bu mesele ile ilgili, " وهذا له غور / bu

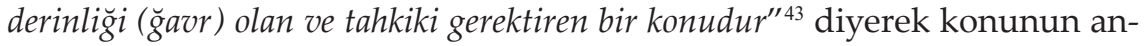
laşılmasının zorluğuna dikkat çekmektedir. Kanaatimizce mubahın şer'î hüküm olup olmaması ile ilgili Mu'tezilî âlimler ile cumhur arasındaki tartışmanın, Râzî̀ ${ }^{44}$ ve Âmidî ${ }^{45}$ gibi usulcülerin dediği gibi lafzî bir tartışma ${ }^{46}$ olarak nitelenmesi uygun değildir. ${ }^{47}$ Çünkü son tahlilde bir taraf mubahı şer'î hükümden kabul ederken diğer taraf şer'î hükümden kabul etme-

${ }^{42}$ H. Yunus Apaydın, “Kurtubalı Zahiri Fakih İbn Hazm'ın Şer'î Hükümleri Tasnifi: Merâtibu'ş-Şeria“", ISTEM: İslâm San'at, Tarih, Edebiyat ve Mûsikîsi Dergisi 7/14 (2009), 117 (33. dipnot). Ayrıca bk. H. Yunus Apaydın, "Fıkıh Usulünün Temel Kabulleri ve Tarihselcilik", Din̂̂ Hükümlerin Kaynağı ve Dinî Metinlerin Anlaşılması Konusundaki Çağdaş Yaklaşımlar Çalıştayı (18-19 Aralık 2009), ed. Cengiz Kallek (İstanbul: İSAM Yayınları, 2010), 330.

${ }^{43}$ Gazzâlî, el-Müstasfâ, 1/245.

${ }^{44}$ Râzî, el-Mahsûl, 2/213-214.

45 Âmidî, el-ìhkâm, 1/166.

${ }^{46}$ Çağdaş usulcülerden Abdülkerim en-Nemle de Mu'tezilî âlimler ile cumhur arasındaki tartışmanın lafzî olduğunu ve hiçbir fıkhî/hukukî semeresi olmadığını söylemektedir. Bk. Nemle, el-Mühezzeb fì ilmi usûlil-fikh el-mukâren (Riyad Mektebetü'r-rüşd, 1999), 1/262.

${ }^{47}$ Krş. Talip Türcan, "Sünnî ve Mu'tezilî Fıkı Usulünün Tanımlanmasında Bir Kriter Olarak Şer'îlik Algısı ve İbâha Alanının Şer'îliği Sorunu Bağlamında Bir Örnekleme", Marife Bilimsel Birikim 3 (2005), 210. 
mektedir. Nitekim Mu'tezilî âlimler, şer'î/dinî bildirim öncesi veya sonrası diye bir ayırım yapmadan ister Şâri'in hitabı ile olsun ister hakkında nass bulunmayan konularda olsun, yapılmasında veya terk edilmesinde günahın olmadığı aklen bilinen tüm mubah fiillerin şer'î hüküm kategorisinden sayılamayacağını söylemektedirler. ${ }^{48}$

Konuyla ilgili tarafların görüş ve açıklamalarından da anlaşılacağı üzere Ka'bî'nin başını çektiği bazı Mu'tezilî âlimler ile cumhur arasındaki tartışmanın özünü, şer'î/dinî bildirim öncesi veya sonrasında diye bir ayırım yapmaksızın, "bir fiilin yapılmasına veya terk edilmesine günahın terettüp edip etmemesinin aklen sabit olup olmaması" oluşturmaktadır. ${ }^{49}$ Şöyle ki; Mu'tezilî âlimler bu konuda, "bir şeyin aslen mubah olması", yani "istishâb/aslî ibaha" ilkesinden hareket etmekteler ve şer'î/dinî bildirim öncesi ve sonrası diye bir ayırım yapmaksızın, bir fiilin yapılmasına veya yapılmamasına günahın /sakıncanın terettüp edip etmemesini esas almaktadırlar. Dolayısıyla konuya bu açıdan bakıldığında mubahın şer'î hüküm kategorisinde değerlendirilemeyeceğini söylemektedirler. Çünkü Ka'bî ve taraftarlarına göre hakkında yasaklayıcı veya emredici bir nass (dinî hüküm) olmadığı sürece, şer'î/dinî bildirim öncesi (aslî ibaha kapsamında) kendisine bir günahın, sorumluluğun (muâheze) ve cezanın (1kâb) sabit olmadığı bir şeyin konumu, Şâri'in hitabı ile sabit olsun veya olmasın şer'î/ dinî bildirim sonrası da aynen devam eder. Buna göre yapılmasının veya yapılmamasının aklen günah olmadığı bilinen bir şey (mubah/aslî ibaha), şer'î hüküm kapsamında yer alamaz. ${ }^{50}$

Mu'tezilî âlimlerin konuyla ilgili değerlendirmelerini dikkate aldığımızda onlara göre bir fiilin şer'î hüküm olmasındaki temel kriter; yapılması veya terk edilmesine sevabın veya 1 kabın (cezanın/günahın) terettüp etmesidir. ${ }^{51}$ Nitekim usulcülerin vâcip, mendup, haram ve mekruhla ilgili tanımlarına baktığımızda da durumun böyle olduğu anlaşılmaktadır. ${ }^{52} \mathrm{Ma}$ hiyeti açısından bakıldığında ise mubah için böyle bir durum/hüküm söz konusu değildir. Mubah kapsamındaki bir fiile sevap ve 1 kabın taalluk etmesi ise onun mahiyeti itibariyle değil, kullanılma amacı ve sonucuna

\footnotetext{
${ }^{48}$ Bardakoğlu, "Câiz", 7/27.

${ }^{49}$ Krş. Şaban, Usûlül-fikh, 275; Apaydın, Hukuk Usulü, 174. Konuyla ilgili ayrıca bk. Türcan, "Şer'îlik Algısı ve İbâha Alanının Şer'îliği Sorunu", 207-211.

${ }^{50}$ Bk. Gazzâlî, el-Müstasfâ, 1/245; Husarî, Nazariyyetül-hükm, 37, 70; Medkûr, Nazariyyetülibâha, 24; Dönmez, "Mubah", 30/341; Türcan, "Şer'îlik Algısı ve İbâha Alanının Şer'îliği Sorunu", 208, 210.

${ }^{51}$ Krş. Zühaylî, Usûlül'l-fikh, 1/88.

${ }^{52}$ Bu kavramların tanımı ile ilgili bk. Ebû Zehra, Usûl, 28, 39, 42, 45 (28-46); Zeydan, el-Vecîz, $27,32,35,37(27-38)$.
} 
göredir. Nitekim mahiyeti açısından mubah olan veya âdetten sayılan bir fiil, niyet ve kasdın bulunması ile tâata/ibadete dönüşebileceği gibi masiyete de dönüşebilmektedir. ${ }^{53}$ Konuya bu açıdan bakıldığında mubahı şer'î hükümlerden kabul etmeyen Mu'tezilî görüşün kısmen haklı olduğunu söylemek mümkündür. Nitekim günümüz İslâm hukukçularından Vehbe ez-Zühaylî (1938-2015) de bu bağlamda Ka'bî ve taraftarlarının görüşüne katıldığını ifade ederek şöyle demektedir: "Bir fiili yapmaya ve terk etmeye günahın (harec) terettüp etmemesinin şer'î ibaha olmadığ 1 konusunda ben de Mu'tezilî âlimlerin (Ka'bî'nin) görüşünün doğru ve haklı olduğunu teslim ediyorum." ${ }^{44}$ İslâm hukukçularının ittifakı ile mubah olan bir fiilin yapılmasına veya yapılmamasına ise günah terettüp etmemektedir. Dolayısıyla Zühaylî'nin bu ifadelerine göre, yapılmasına veya terk edilmesine günahın terettüp etmediği mubahın şer'î hükümden sayılmaması gerekmektedir.

Cumhur ise bir fiile günahın terettüp etmemesinin ancak Şâri'in hitabı, yani şer'î/dinî bildirim ile sabit olacağını söylemektedir. Buna göre bir fiilin yapılmasının veya terk edilmesinin günah olması, ancak şer'î/dinî bildirim sonrasında bilinebilir. Dolayısıyla şer'î hitap ile sabit olan bir fiil, şer'î hüküm kategorisinde yer alı..$^{55}$ Bu bağlamda mubah da Şâri'in hitabı ile sabit olduğu için şer'î bir hüküm olmaktadır. Diğer taraftan Fahreddin er-Râzî (öl. 606/1209) ve Muhibbüllah b. Abdüşşekûr el-Bihârî'nin (öl. 1119/1707) ifadelerine göre Şâri' in sükût ettiği veya hakkında emredici veya yasaklayıcı bir nass/hüküm bulunmayan aslî ibaha da şer'î hüküm kapsamında yer almaktadır. ${ }^{56}$

Mubahın şer'î hüküm kapsamında yer aldığını söyleyen cumhurun bu görüşünü, usulcülere göre nasların (hitabın) doğrudan veya dolaylı olarak tüm hayat olaylarını kuşatması ile de temellendirmek mümkündür. Nitekim usulcülere göre, hükümsüz hiçbir hayat olayı yoktur ve naslar doğrudan veya dolaylı olarak tüm hayat olaylarını kuşatmaktadır. Naslar tüm hayat olaylarını kuşattı̆̆ına göre şer'î açıdan "farz/vacip-mubah-haram" üçgeni dışında bir olayın kalması mümkün değildir. ${ }^{57}$ Dolayısıyla

${ }^{53}$ Şâtıbî, el-Muvâfakât, 2/202. Ayrıca bk. Şâtıbî, el-Muvâfakât, 1/119-120; Zeydan, el-Vecîz, 39.

${ }^{54}$ Zühaylî, Usûlü̈ll-fikh, 1/88.

55 Gazzâlî, el-Müstasfâ, 1/246; Karâfî, Şerhu Tenkîhül-fusûl, 62; Zerkeşî, el-Bahrül- muhît, 1/277278.

${ }^{56}$ Bk. Râzî, el-Mahsûl, 2/213-214; Bihârî, Müsellemü's-ssübût, 1/91. Ayrıca bk. Ensâri, Fevâtihu'rrahamût, 1/91; el-Mevsûatül-fikhiyye, "İbâha”, 1/132.

57 Nasların tüm hayat olaylarını lâfzen veya delâleten kuşatması ile ilgili değerlendirmeler için bk. Şâfiî, er-Risâle, thk. Ahmed Muhammed Şakir (Beyrut: Daru'l-kütübil-ilmiyye, ty.), 19 (nr. 46, 48), 477 (nr. 1326); Bakıllânî, et-Takrîb ve'-irşâd (es-Sağîr), thk. Abdülhamid b. 
nasların kuşatıcılığı açısından bakıldığında cumhura göre mubahın şer'î hüküm olması gerekmektedir. Diğer taraftan cumhura göre mubahın şer'î hüküm kapsamında yer almasının tağlîb (genelleme) yoluyla olduğunu söylemek de mümkündür. Nitekim cumhur, teklif (külfet ve meşakkat) içermemesine rağmen, tağlîb yoluyla -diğer teklîfî hükümlerle birlikte mubahın- teklîfî hükümden olduğunu söylemektedir. ${ }^{58}$ Buna göre, nasıl ki mubahın teklîfi hüküm olması tağlip yoluyla olmuş ise şer'î hüküm olması da tă̆lip yoluyla olmaktadır, diyebiliriz. Çünkü bir fiili yapıp yapmama arasında muhayyer olmak, doğrudan hükümle bağlantılı bir durum değildir. ${ }^{59}$

Gazzâlî, el-Müstesfấda Mu'tezilî âlimlere nispet ettiği mubahın şer'î hüküm olmadığ1 görüşünü naklettikten sonra; " وهذا له غور / bu derinliği

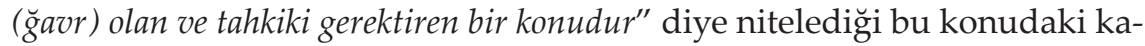
palılığı gidermek için mubah kapsamına giren fiilleri üç kısma ayırmaktadır. Birinci kısım, asıl üzere kalan mubah fiildir (aslî nefy/aslî ibaha). Şer bu fiil hakkında, ne sarih lafızla (doğrudan) ne de sem'î delillerden biri ile (dolaylı olarak) bu konuda hiçbir şey söylememiştir. Bu fiil hakkında, "daha önce olduğu hal üzere devam edip gelmiş ve sem' (şeriat) ona hiç değinmemiştir. Dolayısıyla bu fiil hakkında hiçbir hüküm yoktur" denilmesi gerekir. (Buna göre aslî ibaha, şer'î hükümden değildir.) İkinci kısım, şer'in 'dilerseniz yapın, dilerseniz yapmayın' diyerek yapılıp-yapılmaması konusunda mükellefi muhayyer bıraktığ 1 fiildir. Şer'in bu şekilde, "dilerseniz yapın, dilerseniz yapmayın" demesi bir hitaptır. Hükmün de zaten hitaptan başka anlamı yoktur. Yani hüküm, Şâri'in hitabıdır. Böyle bir hitap varid olduğuna göre bunu inkâr etmek de mümkün değildir. Dolayısıyla şer'î ibaha, şer'î bir hükümdür. Üçüncü kısım ise hakkında, “dilerseniz yapın, dilerseniz yapmayın' şeklinde muhayyer birakan bir hitap (tahyîr) ile sabit olmayan, fakat sem'î/şer'î delilin, yapılmasında ve terk edilmesinde bir günah olmadığına delâlet ettiği fiildir. Bu fiil, sem'î delil, yani Şâri'in hitabı ile

\footnotetext{
Halid Ebu Zenîd (Beyrut: Müessesetü'r-Risâle, 1998), 1/312; Cessâs, el-Fusûl fi't-usûl, 4/7576, 81; Serahsî, el-Usûl, 2/139-140 (Kıyas Konusu); İbn Hazm, el-İhkâm, 8/134; Cüveynî, elBurhân, 2/743-744/r. 676-677 (kıyas konusuna giriş paragrafi); Gazzâlî el-Müstasfâ, 1/20, 3/3; Râzî, el-Mahsûl, 1/167, 169; Şâtıbî, el-Muvâfakât, 1/173; Şevkânî, İrşâdül-fuhûl, 347-348. Ayrıca bk. H. Yunus Apaydın, "İctihad", Türkiye Diyanet Vakfi İslâm Ansiklopedisi (İstanbul: TDV Yayınları, 2000), 21/434; Apaydın, "Fıkıh Usulünün Temel Kabulleri ve Tarihselcilik", 328-331; Mehmet Erdoğan, "İslâm Hukukunun Teolojik Temelleri", İslâm Fikhını Nasıl Anlamalıyız Sempozyum Tebliğ ve Müzakereleri (Bursa: KURAV Yayınları, 2006), 194; Mehmet Erdoğan, "İslâm Hukukunda Şer'îlik Kavramı", İslâmî Araştırmalar Dergisi 19/1 (2006), 151.

${ }^{58}$ Şevkânî, İrşâdül-fuhûl, 23. Ayrıca bk. Zerkeşî, el-Bahru'-muhît, 1/341; Ensârî, Fevâtihu'rrahamût, 1/90; Seyyid Bey, Fıkıh Usulü, 73; Medkûr, Nazariyyetül-ibâha, 286.

${ }^{59}$ Tevhit Ayengin, "Hüküm Teorisi”, İslâm Hukukuna Giriş (Erzurum: Atatürk Üniversitesi Açıköğretim Fakültesi, 2011), 158-159.
} 
bilinmiştir. Şayet bu sem'î delil olmasaydı, bu fiil işleyen kişiden sakıncanın/günahın kaldırıldığı ve bu fiilin aslî nefy, yani aslî ibaha üzere kaldığı "akıl" delili ile bilinirdi. ${ }^{60}$

Gazzâlî, üç kısma ayırdığı ve hakkında "bu derinliği ( (̆gavr) olan / tahkiki gerektiren derin bir konudur" dediği mubah fiillerin şer'̂́liği, yani şer'î hüküm olup olmaması ile ilgili Mu'tezilî âlimlerin yorumunu da haklı çıkaracak şu değerlendirmeyi yapmaktadır:

“Bu üçüncü (yani mubah olduğu ile ilgili hakkında sem'î bir delil bulunmayan ancak, yapılmasında ve terk edilmesinde bir günahın bulunmadığı fiil hakkında nazar vardır. (Yani bu fiiller tarış̧maya açıktır. Dolayısıyla bu konu hakkında farklı görüş ve düşünceler ileri sürülebilir.) Zira bu fiilde akıl ve Sem' delili bir araya gelmiştir. Aynı şekilde diğer iki kısımda, yani aslî nefy/ aslî ibaha ve şer'î ibaha da nazar vardır (Yani hakkında sem'î/şer'î hiçbir delil varid olmayan mubah fiil (aslî ibaha) ile hakkında sem'î/şerî delil bulunan ve Şâri' in hitabı ile sabit olan mubah fiil (şer'î ibaha) da tartışmaya ve farklı görüş beyan etmeye açıktır.). Zira "Şâri'in, 'istersen kalk istersen otur' şeklindeki sözü (yani Şâri'in hitabı ile sabit olan şer'î ibaha) hakkında şöyle denilmesi mümkündür: Şâri'in 'istersen kalk istersen otur' demesi, yeni bir hüküm getirmek (tecdid-i hüküm) değil, aksine önceki hükmü aynen bırakmadır (takrîr). Hükmün takriri ise durumunu değiştirmeyerek onu bulunduğu hal üzere bırakmak demektir. O halde bu, Şer' ile ortaya çıkan yeni bir şey (yeni bir hüküm) değildir, dolayısıyla şer'î (hüküm) de değildir. Diğer kısma -yani hakkında hitap ve delil varid olmayan- gelince; bunun şöyle denilerek inkâr edilmesi mümkündür: Sem', hakkında yapma talebi (talabü'l-fi'l) ve terk etme talebi (talebü't-terk) bulunmayan yerlerde/fiillerde mükellefin muhayyer olduğuna delâlet etmiştir. Bu ise genel olarak, sınırsız sayıdaki filler hakkında (Şâri'in sükûtunun o fillin mubah olduğuna dair şer'î) bir delildir. Buna göre, Şer'in -dolaylı olarak- delâlet etmediği hiçbir fiil kalmaz ve böylece bu fiiller, Şer'/Şâri tarafından mubah kılınmış olur. Aksi takdirde, Şer'in bir şeyi mubah kılmasının değiştirme (tağyir) değil, aynen bırakma (takrir) olduğu; takririn ise yeni bir iş/hüküm olmadığı; aksine, takririn, bu konuda yeni bir hüküm getirilmediğini beyan/açılamak, hatta yeni bir hükme hiç değinmemek olduğu ileri sürülerek karşı çıkılabilir." ${ }^{\prime 1}$

Gazzâlî'nin yukarıda üç kısma ayırdığı ve her biri ile ilgili yaptığı değerlendirmeler, Mutezilî âlimlerin "mubahın şer'î hüküm olmadığı" şeklindeki görüşlerine kısmen haklılık payı verilebileceğini göstermektedir.

${ }^{60}$ Gazzâlî, el-Müstasfâ, 1/245-247.

${ }^{61}$ Gazzâlî, el-Müstasfâ, 1/246-247. 
Açıklama ve değerlendirmeleri dikkate aldığımızda Mu'tezilî âlimler ile cumhur arasındaki ihtilafın, tarafların konuya farklı açılardan bakması ile ilgili lafzî bir tartışmadan ibaret olmadığı anlaşılmaktadır. Dolayısıyla bu konuda; Mu'tezilî âlimlerin şer'î/dinî bildirim öncesi ve sonrası diye bir ayırım yapmadan genel olarak "yapılmasında veya terk edilmesinde günahın olmadığı" fiil anlamında mubahı şer'î hükümden kabul etmediğini söylemek mümkündür. Diğer taraftan cumhurun; “Ka'bî'nin kastettiği mubah, hakkında nass olmayan şer'î/dinî bildirim öncesi için geçerlidir. Bizim kastettiğimiz mubah ise hakkında nass olan şer'î/dinî bildirim sonrasıdır. Dolayısıyla ihtilaf farklı bakış açılarından kaynaklanmaktadır" şeklindeki açıklamaları da anlamsız gözükmektedir. Çünkü istishâb kaidesi çerçevesinde şer'î bildirim öncesi bir fiilin aslî ibahadan sayılması ve bunun şer'î hükümden olmadığının söylenmesi şer'î/dinî bildirim sonrası, yani İslâm şeriatının gelmesi ile anlamsız ve gereksiz bir yorum olmaktadır. Zira İslâm'ın gelmesiyle "şer'î/dinî bildirim öncesi" diye bir durum veya şer'î/dinî bildirim öncesine göre hüküm vermek söz konusu değildir.

Mubahın şer'î hüküm olup olmaması ile ilgili temel sünnî yaklaşımı temsil eden cumhur ile Mu'tezilî âlimler arasındaki yaklaşım farklılığını özetle ifade etmek gerekirse; Mu'tezilî âlimlere göre bir şeyin şer'î hüküm olmasında asıl olan; onun yapılmasına veya terk edilmesine günahın terettüp edip etmemesidir. Buna göre bir şeyin yapılmasında veya terk edilmesinde günah varsa o fiil şer'î hükümdendir, yoksa şerî hükümden değildir. Cumhura göre ise bir şeyin şer'î hüküm olmasında asıl olan; Şâri'in hitabının olup olmamasıdır. Buna göre bir şeyin yapılmasında Şâri'in hitab1 varsa o fiil şer'î hükümdendir yoksa şer'î hükümden değildir. ${ }^{62}$ Ancak son tahlilde cumhura göre bir meselenin mubah kategorisinde yer alması Şâri'in doğrudan hitabı ile olabileceği gibi dolaylı hitabı ile de olabilmektedir. Nitekim Râzî ve Bihârî'nin sarih olarak ifade ettikleri gibihakkında nass olmayan (meskûtün anh) aslî ibaha kapsamındaki konular da şer'î ibahadan sayılmaktadır. ${ }^{63}$ Sonuç olarak:

“İbaha alanının şer'î mi yoksa aklî mi olduğuna ilişkin tartışma, tarafların şer'îlik algısındaki farklılığın bir yansımasıdır. Temel sünnî yaklaşım, her beşeri davranışın ancak şer' yoluyla bilinebilen bir hükmünün olduğu ve hiçbir davranışın şer'î değerlendirme dışında kalmadığı şeklindedir. Dolayısıyla kişilerin serbestçe hareket etme imkânına sahip oldukları ibaha alanı, şer'in vâcib, mendûb, haram veya mekruh kılmaması sebebiyle mubah olduğu anla-

${ }^{62}$ Türcan, "Şer'îlik Algısı ve İbâha Alanının Şer'îliği Sorunu", 208, 210-211.

${ }^{63}$ Râzî, el-Mahsûl, 2: 213-214; Bihârî, Müsellemü's-sübût, 1/91. 
şılan davranışlar bütünü demek değildir. Bir davranış, tıpkı vâcib veya haram nitelikli davranışlarda olduğu gibi ancak şer'in bildirmesi ile mubah hale gelebilir. Hâlbuki ibaha alanının aklî olduğunu savunan yaklaşımda -kimi sünnî usulcüler de aynı görüşü paylaşmaktadır- mubah, şer'in müdahale etmediği; aklın, yapılmasını ve yapılmamasını eşit düzeyde değerlendirdiği davranış biçiminde tanımlanmaktadır." ${ }^{64}$

\section{MUBAHIN ŞER'Î HÜKÜM OLUP OLMAMASININ KAMU OTORITESININN MUBAHI SINIRLANDIRMA YETKİSİ İLE İLISSKİLENDİRILMESİ}

\subsection{Konuyla İlgili Mansurizâde Said'in Görüşü}

Osmanlının son dönem düşünürlerinden hukukçu Mansurizâde Mehmed Saîd (1864-1923)65, mubahın şer'î hüküm olup olmaması ile kamu otoritesinin mubahı sınırlandırma yetkisi arasında bir ilişki kurmakta ve mubahın şer'î hüküm kapsamında yer almadığını, dolayısıyla kamu otoritesinin mubah/cevâz olarak isimlendirilen hukukî serbest alanda mutlak olarak tasarruf yetkisine sahip olduğunu söylemektedir. Nitekim Mansurizâde Said konuyla ilgili görüşlerini, İslâm Mecmuası'nda ${ }^{66}$, "Cevâzın Ahkâmı Şer'iyyeden Olmadığına Dâir"; "Kanun ve Şeriat" ve “Taaddüd-i Zevcât İslâmiyette Men Olunabilir" konuları etrafında yazdı̆̆ı makalelerinde açık ve net olarak ifade etmektedir. ${ }^{67}$

Konuyla ilgili görüşlerinde Mu'tezilî yaklaşımı esas alan Mansurizâde Saîd, şer'î/dinî bildirim öncesi ve sonrası diye bir ayırım yapmadan, bir başka ifade ile Şâri'in hitabı ile sabit olup olmamasına bakmaksızın ister "şer'î ibaha" olsun ister "aslî ibaha" olsun mubahın/cevazın ahkâm-1

64 Türcan, "Şer'îlik Algısı ve İbâha Alanının Şer'îliği Sorunu”, 210.

${ }^{65}$ Mansurizâde Saîd'in hayatı ve eserleri ile ilgili bk. Abdullah Kahraman (Yayına Haz. "Şeriat ve Kânûn (Mansurizâde Mehmed Saîd)", İslâmiyât (Şeriat Dosyası) 1/4 (EkimAralık 1998), 239-241 (Sunuş kısmı); Abdullah Kahraman, "Daru'l-Fünûn Hocalarından Mansûrizâde Mehmed Saîd Ve Klasik Fıkhın Sınırlarını Zorlayan Bazı Görüşleri", Daru'Fünûn İlahiyat Sempozyumu (18-19 Kasım 2009) Tebliğleri (İstanbul: 2010), 405-407; Ayşegül Yılmaz, Mansurizâde Saîd ve Fıkhî Görüşleri (İstanbul: Marmara Üniversitesi, Sosyal Bilimler Enstitüsü, Yüksek Lisans Tezi, 2003), 7-25.

${ }^{66}$ İslâm Mecmuası, I. Dünya Savaşı yıllarında yayımlanan bir fikir dergisidir. Geniş bilgi için bk. Tuba Çavdar Karatepe, "İslâm Mecmuası", Türkiye Diyanet Vakfı İslâm Ansiklopedisi (İstanbul: TDV Yayınları 2001), 23/53-54.

${ }^{67}$ Mansurizâde Saîd'in konuyla ilgili görüşleri için bk. Mansurizâde Saîd, "Cevâzın Ahkâm-1 Şer'iyyeden Olmadı̆̆ına Dâir", 295-303; "Taaddüd-i Zevcât İslâmiyette Men Olunabilir", 233-238; "Şeriat ve Kanun-I", Daru l-Funun Hukuk Fakültesi Mecmuası (DFHM) 1/6 (İstanbul 1332-1334), 530-535; “Şeriat ve Kanun-II”, Daru'-Funun Hukuk Fakültesi Mecmuası (DFHM) 2/8 (İstanbul 1332-1334), 601-606. Ayrica bk. Aydın, Aile Huku, 172-174; Niyazi Berkes, Türkiye'de Çă̆daşlaşma (Ankara: Bilgi Basımevi, 1973), 395-396. 
şer'iyyeden olmadığını ve kamu otoritesinin (devlet başkanının) mutlak anlamda mubahı sınırlama yetkisinin olduğunu makalelerinde teferruatlı bir şekilde ele almaktadır. Konunun daha açık ve net olarak ifade edilebilmesi için Mansurizâde Said'in görüşlerinden bazı kesitler aktarmak uygun olacaktır. Mansurizâde Said, "Cevâzın Ahkâm-ı Şer'iyyeden Olmadığına Dair" isimli makalesinde konuyla ilgili şöyle demektedir:

“Cevâz, şer'î bir hüküm değildir. Çünkü şeriat, nizamı ve intizamı korumak maksadıyla vaz' ve tesis olunmuş bir konundan ibarettir. Kanun, fiil ve davranışları kayıt altına almak için vaz' edilir. Kayıtlandırmaya yarayan hükümler ise, vücûb ve hürmet gibi hükümlerdir. Sıhhat ve fesâd gibi hükümler de şer'î emir ve nehyin neticesi olduklarından vücûb ve hürmet manalarını içine alırlar. Bu sebeple onlar da kayıtlandırmaya yardımcı olur. Cevâz ise, bir fiil ve hareketin serbest oluşundan ibaret olup kayıtlandırmaya hizmet etmez. Dolayısıyla da şeriatın hükümlerinden sayılmaz." ${ }^{68}$

“... İzah ve tafsil ettiğim (ayrıntılı olarak açıkladığım) üzere cevâz, öyle ileri sürdükleri şekilde ne Şâri'in hitâbı ve ne de hitabının sonucudur. Cevâz, Şâri' in hitâbı değil, hitabının olmayışıdır. Hitâbının sonucu da değil, hitabının olmayışının sonucudur. Bu sebeple cevaza 'hüküm' denemez, hiçbir şekilde şeriatın hükümlerinden sayılamaz." 69

“İşte böyle körü körüne (ale'l-umyâ) cevâz hakkında 'hitâbın sonucudur' diye hükmedilmiş ve bu esâs-1 fâsid (çürük temel) üzerine bina ederek cevâz şer'î ahkâmdan sayılmış ise de arz ve izah ettiğim gibi; cevâz hitâbın sonucu değildir ki şer'î ahkâmdan sayılabilsin. Böyle ahkâm-i şer'iyyeden olmayan cevâza tabiatiyle şeriat müdahale etmeyeceğinden ${ }^{70}$ taaddüd-i zevcât (çok kadınla evlilik), evlenme, boşanma gibi câiz olan şeyler hakkında ülü'l-emr yani hükümet milletin vicdanına ve asra uygun şekilde hükümler ve kanunlar vaz' ve tesis edebilir." ${ }^{71}$

${ }^{68}$ Mansurizâde Said, "Cevâz Ahkâm-1 Şer'iyyeden Olmadığına Dair", 296. Ayrıca bk. Ali Bardakoğlu (sadeleştiren), "Mansurizâde Saîd: Cevâz Şer'i Ahkâmdan Olmadığına Dâir". Erciyes Ünv. Sosyal Bilimler Ens. Dergisi 1 (Kayseri 1987): 82.

${ }^{69}$ Mansurizâde Said, "Cevâz Ahkâm-1 Şer'iyyeden Olmadığına Dair", 301. Ayrıca bk. Bardakoğlu (sadeleştiren) “Mansurizâde Said: Cevâz Şer'î Ahkâmdan Olmadığına Dair", 87.

${ }^{70}$ Burada Mansurizâde Said'e şöyle bir itiraz yapılabilir: İnsanın (müctehidin) ve devletin karıştığı bir konuya şeriat (din) niçin karışmasın? Ayrıca bir şeyin şer'î hükümden olması ona insanın (müctehidin) karışamayacağı anlamına mı gelmektedir? Nitekim Şâri', nassların yorumunda akla (sivil insiyatife/ müctehidlere) geniş yorum hakkı vermiştir. Bundan dolayıdır ki İslam hukukçuları, şer'î hükümden olan farz/vacip, mendup (sünnet), mubah, mekruh, haram ile ilgili her mesele hakkında Şâri'in maksadı doğrultusunda ictihadda (yorumda) bulunmuşlar ve konuyla ilgili görüşlerini beyan etmişlerdir. Nitekim İslâm hukukçuları da müctehidlerin bu ictihadlarının şer'î bir hüküm olduğunu ve avam (mukallitler) için şer'î deliller konumunda olduğunu söylemişlerdir. Bk. Şâtıbî, elMuvâfakât, 4/244-246, 292-293.

${ }^{71}$ Mansurizâde Said, "Cevâz Ahkâm-1 Şer'iyyeden Olmadığına Dair", 303. Ayrıca bk. 
Konuyu kendi bakış açısından fıkıh usulünde belirli bir zemine oturtan Mansurizâde Said, "Taaddüd-i Zevcât İslâmiyette Men Olunabilir" isimli makalesinde ise konuyla ilgili şöyle demektedir:

“Demek oluyor ki hakkında emir ve nehy-i şer'î varid olmamış, vacib ve memnu' olmayan hangi bir şey hakkında olursa olsun -ki caiz olan hangi bir şey olursa olsun demektir- ülüll-emr, emr veya nehy ederse vacib olan bir şeyin hilafını veya bir fi'l-i memnuyu emr etmediği içün, hülasa şeriatın hiçbir emr ve nehyine muarız olmadığı içün kâffesine itaat etmek vaciptir. İşte bu hüküm her türlü şek ve tereddüdden hâli, nass-1 mezkûrun müfâd-1 kat'î ve muktezây-1 sarîhidir... Binaen aleyh emr ve nehy-i şer'î vârid olmamış câiz olan şeylerin kâffesinde ülül-emrin emr ve nehyettmeye, kâbil-i takyîd ve tahdîd olmayan selâhiyet-i vâsıası/sınırsız tasarruf yetkisi vardır."72

"Hulâsa şerîat-i İslâmiyyede şurası muhakkaktır ve her türlü şek ve tereddüdden, hilaf ve ihtilafdan mâ'sundur ki ale'1-umûm câiz olan şeylerde ülü'lemrin emr ve nehy etmeye selâhiyat-ı vâsiası vardır... Binaen aleyh ülü'l-emr, yani hükümet, bi'l-külliyye (umûr-1 caizeden/mubah olan) taaddüd-i zevcâtı men etmeye veya bazı kuyûd ve şurût ile takyîd etmeye selâhiyet-i tâmmesi vardır. Şeriat-1 İslâmiyyede, arzettiğim veçhile bu hususda hiçbir mâni yoktur. Çünkü ale'l-umûm câiz olan şeylerde emr ve nehye ve kavânîn vaz'ına ülü'1emrin nazar-1 şarîatte selâhiyat-i vâsıası vardır."73

Devlet başkanının, mubah/cevaz alanda her türlü tasarruf etmeye hak ve yetkisinin olduğunu söyleyen Mansurizade Said, "Kanun ve Şerîat"77 isimli makalesinde ise devletin aile hukuku alanında zamanın şart ve icaplarına göre gerekli her türlü düzenlemeyi yapabileceği ile ilgili şöyle demektedir:

"Hülasa: Bâlada bast ve beyan eylediklerimizden (yukarıda genişçe açıkladıklarımızdan) anlaşılacağı vechile... ulü'l-emrin kavânîni sâirede nasıl ihtiyâcât ve mesâlih-i nâsı teemmül ederek birçok kavânîni va'z ve ta'dîl ettiği gibi hukuk-1 medeniyyenin mühim bir kısmını teşkil etmesi lazım gelen münâkahatta da kezalik ihtiyâcât-1 darûriyye ve medeniyyeye muvafık bir surette -saltanat-1 velâyet-i hasebiyle- bilâ kayd ve şart kanun vaz' ve ta'dîl

Bardakoğlu (sadeleştiren) “Mansurizâde Said: Cevâz Şer'î Ahkâmdan Olmadığına Dair”, 89.

${ }^{72}$ Mansurizâde Said, "Taaddüd-i Zevcât İslâmiyette Men Olunabilir", İslâm Mecmuası 1/8 (İstanbul 1330), 236.

${ }^{73}$ Mansurizâde Said, "Taaddüd-i Zevcât İslâmiyette Men Olunabilir", İslâm Mecmuası 1/8 (İstanbul 1330), 237.

${ }^{74}$ Mansurizâde Said, "Şeriat ve Kanun-I", Daru'-Funun Hukuk Fakültesi Mecmuası (DFHM) 6 (1332-1334), 530-535; "Şeriat ve Kanun-II", Daru'-Funun Hukuk Fakültesi Mecmuası (DFHM) 8, (1332-1334), 601-606. Bu makaleler Abdullah Kahraman tarafindan yeni harflerle neşredilmiştir. Bk. Abdullah Kahraman (Yayına Haz.), "Şeriat ve Kânûn (Mansurizâde Mehmed Saîd)", İslâmiyât (Şeriat Dosyası) 1/4 (Ekim-Aralık 1998), 239-251. 
etmeye hak ve selâhiyeti mutlaktır. Buna şer'an hiçbir mâni yoktur."75

Mansurizâde Said'in, mubahın/cevazın şer'î hüküm olup olmaması ve devlet başkanının mubahı sırlama yetkisi ile ilgili makalelerinde özetle söylediği ise şudur:

“Mubah/cevâz, şer'î hükümlerden değildir. Dolayısıyla ülü'l-emr (devlet başkanı/hükümet), velâyet-i saltanat (velâyet-i âmme/selâhiyet-i tâmme) hasebiyle umur-1 câizeden olan mubahta şeriatın men etmediklerini kanun yoluyla menedebilir ve mubah (câiz) olan konularda da gerekli hukûkî düzenlemeleri yapabilir."76

Günümüz İslâm hukukçularından Abdullah Kahraman da "Mansurizâde Saîd'in Klasik Fıkıhçılara Yönelttiŏi Bazı Eleştiriler" isimli makalesinde Mansurizâde Saîd'in konuyla ilgili yaklaşımını haklı ve isabetli bularak şöyle demektedir:

“Hangi hedefe matuf olursa olsun, Mansûrîzâde'nin usulcü ve fıkıhçların kabullerinden hareketle tespit ettiği problemleri ciddiye almak gerekir. Bize göre, Mansûrîzâde'nin cevâzla ilgili görüşlerinde büyük ölçüde haklılık payı vardır. Onun bu konuda fukahâyı eleştirirken öne sürdüğü gerekçe oldukça tutarlı gözükmektedir. Ona göre şeri'î hüküm Şâri'in hitabının eseriyse bu kapsama vücup ve hurmete ilişkin olanları dâhil edip, hakkında hitap bulunmayanları da cevaz alanına katmak daha isabetlidir." ${ }^{77}$

Cevazın şer'î hüküm olmadığını söyleyen ${ }^{78}$ günümüz İslâm hukukçularından Ali Bardakoğlu ise Mansurizâde Saîd ile benzer bir değerlendirme yaparak şöyle demektedir:

“Mutezile âlimleri mubahı şer'î hüküm kategorisine dâhil etmezken Sünnî düşüncede mubah şer'î hükümdür. Ancak mubahın şer'î hüküm sayılmaması daha isabetli görünmektedir. Şer'î hüküm ya vaciptir ya menduptur ya mekruhtur ya da haramdır; geri kalan geniş alan ise aslî ibâha kuralı kapsar. Câiz ve mubah şer'î hüküm kategorisinde yer aldığında buna getirilecek sınırlama ve yorum doğrudan şer'î bir hükümde tasarrufun kurallarına tabi olacaktır. Osmanlının son döneminde âlimler bu konuyu tartışmaya açmışlar, şer'î hüküm olmadığını savunan önemli bir grup çıkmıştır." ${ }^{79}$

\footnotetext{
${ }^{75}$ Mansurizâde Saîd, "Şerîat ve Kânûn-I", 535; Kahraman, "Şerîat ve Kânûn (Mansurizâde Saîd)", 247. Ayrıca bk. Aydın, Aile Hukuku, 173.

${ }^{76}$ Kaynakça için bk. Illgili Dipnot.

77 Abdullah Kahraman, "Mansurizâde Saîd'in Klasik Fıkıhçılara Yönelttiği Bazı Eleştiriler", Cumhuriyet Ünv. İlahiyat Fak. Dergisi 5/1 (Sivas 2001): 237.

${ }^{78}$ Ali Bardakoğlu, "Osmanlı Hukukunun Şer'îliği Üzerine”, Osmanlı (Teşkilat içinde). ed. Güler Eren (Ankara: Yeni Türkiye Yayınları, 1999), 6/415.

${ }^{79}$ Ali Bardakoğlu, “Fıkıh Çözüm mü Üretir, Sorun mu?", EskiYeni: Anadolu Illahiyat Akademisi
} 
Yukarıda görüşlerini naklettiğimiz başta Mansurizâde Said olmak üzere Ali Bardakoğlu ve Abdullah Kahraman'ın ifadelerinden mubahın şer'î hüküm olup olmaması ile kamu otoritesinin mubahı sınırlandırma yetkisi arasında bir ilişki kurulduğu anlaşılmaktadır.

\subsection{Değerlendirme}

Mansurizâde Said ve onun görüşüne katılan günümüz İslâm hukukçuları her ne kadar mubahın şer'î hükümden olup olmaması meselesi ile kamu otoritesinin mubahı sınırlandırma yetkisi arasında bir ilişki kurmaya çalışsalar da bu iki konu arasında doğrudan bir ilişki olmadığını söylemek mümkündür. Zira "Mubah, vesile olduğu şeyin hükmünü alır"80 kaidesi gereğince vesile olduğu maslahat ve mefsedete göre mubahın farklı hükümler alabileceği, bir diğer ifade ile şartlar ve ihtiyaçlar gerekli kıldığında kamu yararı ve zararın izalesi bağlamında kamu otoritesinin mubahı sinırlandırma yetkisi İslâm hukukunun müsellem konularındandır. Dolayısıyla kamu otoritesi tarafından sınırlandırmaya söz konusu olabilmesi için mubahın şer'î hüküm kapsamında yer alıp almaması önemli değildir.

Nitekim cevazın ahkâm-ı şer'iyyeden olmadığını aklî ve naklî deliller ile ispat etmeye çalışan Mansurizâde Saîd, mubah şer'î hükümden kabul edilse bile bu durumun mubahın kamu otoritesi tarafından sınırlandırılmasına mani olamayacağı ile ilgili şöyle demektedir:

“Cevazın ahkâm-1 şer'iyyeden olduğu farz edilse bile -taaddüd-i zevcât hakkında yazmış olduğum makalede ispat ettiğgim vechile- yine hükümetin (ülü'lemr'in) bunlar hakkında (câiz/mubah olan alanlarda) kanunlar vaz' ve tesis etmeye hak ve yetkisi red ve inkâr edilemez. Fakat böyle (yani izah ve ispat

Araştırma Dergisi 29 (Güz 2014), 174. Krş. H. Yunus Apaydın, "Siyasal Hayat", İlmihalII (İslam ve Toplum) (Ankara: Türkiye Diyanet Vakfı Yayınları, 2013), 2/293. Yukarıdaki ifadelerinde Mansurizâde Saîd'in görüşlerine katılan ve mubahın/cevazın şer'î hüküm kapsamında olmadığını söyleyen Bardakoğlu'nun aşağıdaki ifadeleri ise Şâri'in sükût ettiği ve hakkında yasaklığın bulunmadığı hukukî serbest alanların da şeriat/şer'î hüküm kapsamında olduğunu göstermektedir:

“Bir hukuk normunun veya uygulamasının İslâm'a uygunluğu, yani klasik ifadesiyle şer'îlı̣̆̂ denilince onun, dinin açı hükümlerine aykırı olmaması kastedilir. Bu da Kur'an ve Sünnet'te yer alan ifadenin onu emretmesi, uygunluğunu açıkça teleffuz etmesi şeklinde olabileceği gibi ona ilişkin bir açıklamaya yer vermemesi, yani yasaklığından söz etmemesi şeklide de olabilir." (Bardakoğlu, "Osmanlı Hukukunun Şer'îliği Üzerine”, 414.)

${ }^{80}$ Bu fikhî kaide ile ilgili bk. İbn Abdüsselâm, Kavâidül'-ahkâm fi mesâlihi'l-enâm, thk. Nezih Kemal Hammad ve Osman Cuma Damiriyye, (Dimeşk: Dâru'l-Kalem, 2000), 1/34-36, 74; Karâfî, el-Furûk, 2/61 (Fark: 58); Şâtıbî, el-Muvâfakât, 1/113, 114, 125, 128, 4/194; İbn Kayyim, Îlâmül-muvakkîn an rabbil-âlemîn, (Riyad: Dâru İbnül Cevziyye, 1423 h.), 4/553; Ebû Zehra, Usûl, 288; Medkûr, Nazariyyetül-ibâha, 96, 99, 433; Zeydan, el-Vecîz, 195, 197; Zühaylî, Usûlül'l-fikh, 2/874, 877-882. 
ettiğim üzere) cevaz ahkâm-1 şer'îyyeden sayılmayacağı için mesele (yani devlet başkanının mubahı sınırlandırması) daha basit bir şekilde halledilmiş olur ve izaha ve ispata gerek kalmaz" ${ }^{\prime 1}$

Mansurizâde Said'in görüşlerine karşı cevazın/mubahın ahkâm-1 şer'iyyeden olduğunu savunan İzmirli İsmail Hakkı (1869-1946) ${ }^{82}$ ve (Babanzâde) Ahmed Naim (1872-1934) ${ }^{83}$ de şartların ve ihtiyaçların, bir diğer ifade ile kamu yararının gerektirmesi halinde prensip olarak devlet başkanının; yani kamu otoritesinin mubahı/cevâzı sınırlandırma hak ve yetkisinin olduğunu kabul etmektedirler. Nitekim İzmirli İsmail Hakkı bu bağlamda; "ef'âl-i mubah hiçbir kimseye eza etmemek şartıyla câiz olur"84; "fil-i mubah bi şartı's-selame câiz olur" 85 fikı kaidelerini aktarmakta ve "harama vesile olan mubah haram, vâcibe vesile olan mubah da vâcip olur" cevâzın/mubahın gaye ve sonucuna göre sınırlandırılmasının mümkün olduğunu söylemektedir. ${ }^{87}$ (Babanzâde) Ahmet Naim ise, "Haydi muvakkaten davanız teslim edeyim de umur-i mubah ve câizenin kâffesinde ümeraya itaat, emri dini gibi vâcib olur diye kabul edeyim..." diyerek prensip olarak kamu otoritesinin cevâzda/mubahda tasarruf yetkisi olduğunu ima etmekte, ancak bu yetkinin iyi niyetle kamu yararının bir gereği olarak değil, dış güçlerin/batının baskısından kaynaklandı̆̆ını ifade etmektedir. ${ }^{88}$

Günümüz İslâm hukukçularından H. Yunus Apaydın da, dinin tüm hayat olaylarını kuşattığını ve mubahın da şer'î hüküm kapsamında yer

${ }^{81}$ Mansurizâde Saîd, "Cevâzın Ahkâm-1 Şer'iyyeden Olmadığına Dâir", 303. Ayrıca bk. Bardakoğlu (sadeleştiren) "Mansurizâde Said: Cevâz Şer'î Ahkâmdan Olmadığına Dair", 89.

82 İzmirli İsmail Hakkı'nın hayatı, eserleri ve görüşleri hakkında geniş bilgi için bk. İsmail Kara, Türkiye'de İslâmcıllk Düşüncesi (İstanbul: Risale Yayınları, 1987), 2/89-135: Ali Birinci-M. Sait Özervarlı, "İzmirli, İsmail Hakkı", Türkiye Diyanet Vakfı İslâm Ansiklopedisi (İstanbul: TDV Yayınları, 2001), 23/530-535.

83 (Babanzâde) Ahmed Naim'in hayatı, eserleri ve görüşleri hakkında geniş bilgi için bk. Kara, Türkiye'de İslâmcllk Düşüncesi, 1/273-308; İsmail Lütfi Çakan, "Babanzade Ahmet Naim", Türkiye Diyanet Vakfi İslâm Ansiklopedisi (İstanbul: TDV Yayınları, 1991), 4/375-376.

${ }^{84}$ Ebu Saîd el-Hâdimî, Mecâmiul-hakâik, nşr. Şirketü Sahafiyye Osmaniyye müdürü el-Hâc Ahmed Hulûsî (İstanbul: Matbaa-i Âmire, 1308), 45 (Hâtime: Kavâid-i külliye, md. 25). الأفعال المباحة إنما بتحز بشرط عدم إيذاء أحد

85 İbn Âbidîn, Muhammed Emin, Reddü̈-muhtâr ale'd-Dürril-muhtâr şerhu Tenvîril-ebsâr, thk. Adil Ahmed Abdülmevcud ve Ali Muhammed Muavvad (Riyad: Dâru Alemi'l-kütüb, 2003), (Kitabü'l-cinâyet/Babü'l-kûd fîmâ dünen nefs/Faslün fi'l-fi'leyn), 10: 219; Mecelle, md. 1254.

الأصل أن الواجب لا يتقيد بوصف السلامة والمباح يتقيد به ومنه ضرب الأب ابنه تأديبا أو الأم أو الوصي

86 İzmirli İsmail Hakkı, "Cevâz Ahkâm-1 Şeriattan Olup Olmaması Hakkındaki Niza Niza-i Lafzidır", 301

87 İzmirli İsmail Hakkı, "Cevâz Ahkâm-1 Şeriattan Olup Olmaması Hakkındaki Niza Niza-i Lafzidır", 300-301.

${ }^{88}$ Ahmet Naim, "Taaddüd-i Zevcat İslâmiyet'te Men Olunabilir mi imiş?: Mansurizade Said Beyefendi'ye", 220. 
aldığını belirterek ${ }^{89}$ kamu otoritesinin cevazda, yani mubah alanda tasarruf yetkisinin olduğunu ifade etmektedir..$^{90}$

Diğer taraftan Hz. Peygamber'in ve Hz. Ömer'in mubahın sınırland1rılmasına yönelik bazı uygulamaları da kamu otoritesinin mubahı sınırlandırma yetkisi ile mubahın şer'î hüküm olup olmaması arasında doğrudan bir ilişki olmadığını göstermektedir. Nitekim Hz. Peygamber'in arızî ve haricî bazı sebeplerden dolayı aslen mubah olan kurban etlerinin üç günden fazla biriktirilmesini $i^{91}$, sığır etinin yenilmesin $\imath^{92}$ ve kabir ziyaretlerin $i^{93}$ yasaklaması; kokusuyla çevreye rahatsızlık veren sarımsak vb. şeyleri kendisinin yememesi $i^{94}$ ve bunlar yiyen kişileri de mescide gelmekten men etmesi ${ }^{95}, k ı z$. Hz. Fatıma üzerine Hz. Ali'nin ikinci bir kadınla evlenmesini yasaklaması ${ }^{96}$ gibi örnekler kamu yararının gerektirmesi, başkalarının hakkına tecavüz etmesi, onlara zarar vermesi vs. gibi gerekçelerin bulunması halinde mubahın sınırlandırılabileceğini göstermektedir. ${ }^{97}$

Hz. Ömer'in hilâfeti döneminde temettu haccin $\imath^{98}$ yasaklayarak ifrad haccln ${ }^{99}$ emretmesi ${ }^{100} ;$ Hz. Huzeyfe (r.a) ve diğer bazı sahabileri Ehl-i kitap kadınlarla evlenmekten men etmesi ${ }^{101}$; kadınların dengi olmayan erkekler-

89 Bk. Apaydın, "Fıkıh Usulünün Temel Kabulleri ve Tarihselcilik", 328-331. Ayrıca bk. H. Yunus Apaydın, Din ve Fıkıh Yazıları (Konya: Hacıveyszade İlim ve Kültür Vakfı Yayınları, 2018), 70, 192-195.

90 Apaydın, "F1kılh Usulünün Temel Kabulleri ve Tarihselcilik", 362. Ayrıca bk. Apaydın, Din ve Fikıh Yazıları, 178, 233.

${ }^{91}$ Konuyla ilgili rivayetler için bk. Buhârî, "Edâhî”, 16; Müslim, "Edâhî", 5; Muvatta, "Edâhî”, 4, 6; Muvatta, "Dahâyâ", 4.

92 Ebû Abdillah el-Huseyin b. Hasen el-Halîmî, el-Minhâc fî̀ şuabil-îmân, thk. Halîmî Muhammed Kûde, (Beyrut: Daru'l-fikr, 1979), 2/31.

${ }^{93}$ Konuyla ilgili rivayetler için bk. Müslim, "Cenâiz", 36; Ebû Dâvûd, "Cenâiz", 77; İbn Mâce, "Cenâiz", 48.

94 Ebû Dâvûd, "Et'1me", 40; Müslim, "Eşribe", 31; İbn Mâce, "Et'1me", 59.

95 Ebû Dâvûd, "Et'1me", 40. Ayrıca bk. Buhârî, "Ezân", 160.

${ }^{6}$ Konuyla ilgili rivayetler için bk. Buhârî, "Nikâh", 109; Müslim, "Fadâilü's-sahâbe”, 15; Ebû Dâvûd, "Nikâh", 12; İbn Mâce, "Nikâh", 56.

97 Krş. Şâtıbî, el-Muvâfakât, 1/147, IV, 60.

98 Temettu haccl: Hac mevsiminde ihrama girip umre yaptıktan sonra ihramdan çıkarak hac vaktine kadar Mekke'de ihramsız olarak durmak ve hac vakti gelince tekrar ihrama girmek suretiyle yapılan hac şeklidir.

99 Ifrad haccl: Hac mevsiminde sadece hac ibâdeti için ihrama girerek yapilan hacc şeklidir.

${ }^{100}$ Bk. Tirmîzî, "Hac", 13. Ayrıca bk. İbn Kayyim, et-Turuku'l-hükmiyye fi's-siyaseti'ş-er'iyye, thk. Nayif b. Ahmed el-Hamed (Mekketü'1-Mülerrame: Dâru Âlemi'l-fevaid, 1428 h), 1/4647; Muhammed Biltâcî, Menhecü Ömer İbnül-Hattâb fi't-teşrî: Dirâse müstev'ıbe li fikhi Ömer ve tanzîmihî (Kahire: Dâru'l-fikri'l-Arabî, 1970), 338-342.

${ }^{101}$ Bk. Kurtubî, el-Câmi li ahkâmi'-Kur'ân, thk. Abdullah b. Abdulmuhsin et-Türkî (Beyrut: Müessesetü'r-risâle, 2006), 3/456; Cessâs, Ahkâmü'-Kur'ân, 3/323. Ayrıca bk. Biltâcî, Menhecü Ömer fi't-teşrî', 301-306; Dirînî, Nazariyyetü't-teassüf, 166-169. 
le evlenmesini yasaklamasi ${ }^{102}$; müellefe-i kulûba zekât fonundan pay ayrılmasını kaldırmass ${ }^{103}$; sahabenin ileri gelenlerinin Medine'den ayrılarak başka yerlere gitmesini yasaklamasi ${ }^{104}$ ve haftada iki gün üst üste et yenilmesini yasaklamas $1^{105}$ gibi uygulamaları da kamu yararının gerektirmesi veya zararın giderilmesi bağlamında kamu otoritesinin mubahı sınırlandırabileceğini göstermektedir.

Sonuç olarak yukarıdaki açıklama ve görüşlerden mubahın şer'î hüküm olup olmaması ile kamu otoritesinin mubahı sınırlandırma yetkisi arasında doğrudan bir ilişki olmadığı anlaşılmaktadır. Nitekim yukarıda zikredilen Hz. Peygamber'in ve Hz. Ömer'in mubahın sınırlandırılmasına yönelik uygulamaları, mubahın şer'î hüküm olup olmaması ile mubahın kamu otoritesi tarafındna sınırlandırılması arasında doğrudan bir ilişki olmadığını göstermektedir. Dolayısıyla "mubahın şer'î hüküm olup olmaması" konusunda cumhur ile Ka'bî'nin başını çektiği Mu'tezilî âlimler arasındaki bu tartı̧̧ma ve bu çerçevede son dönemlerde gündeme getirilen görüşler; "mubahın teklîfî hüküm olup olmaması", "mubahın emredilmiş olup olmaması", "mubahın talep içerip içermemesi" konularında olduğu gibi gereksiz bir tartışma olup fürû-i fıkıh açısından hiçbir fıkhî semeresinin olmadığını söylemek mümkündür. ${ }^{106}$ Nitekim günümüz İslâm hukukçularından Mehmet Erdoğan, İslâmî öğretide nasların tüm hayat olaylarını doğrudan veya dolaylı olarak kuşatmasından hareketle "cevazın şer'î hüküm olup olmaması" ile ilgili tartışmanın gereksiz ve yersiz olduğu ile ilgili şu değerlendirmeyi yapmaktadır:

“... Aynı şekilde vahyin (nasların) gerek adını koyarak gerekse prensibini vaz' ederek değinmediği herhangi bir konu da olmayacak, başka bir ifade ile hukukta bilinçli ya da bilinçsiz bir boşluk bulunmayacaktır. Yani tümüyle beşer

\footnotetext{
${ }^{102}$ Serahsî, el-Mebsût, (Beyrut: Dâru'l-ma'rife, 1989), 4/196.

${ }^{103}$ Bk. Cessâs, Ahkâmül-Kur'ân, 4/325; Serahsî, el-Mebsût, 3/9; Kâsânî, Bedâiu's-sanâi' fì tertîbi'ş-şerâi', thk. Ali Muhammed Muavvad (Beyrut: Dâru'l-kütübi'l-ilmiye, 2003), 2: 470. Ayrıca bk. Cengiz Kallek, "Müellefe-i Kulûb", Türkiye Diyanet Vakfi İslâm Ansiklopedisi (İstanbul: TDV Yayınları, 2006), 31/475-476; Muhammed Muhammed el-Medenî, Nazarât fì fikhi'l-Farûk Ömer ibni'l-Hattâb (Kahire: 2002), 45-54; Biltâcî, Menhecü Ömer fi't-teşrî, 175191; Muhsin Koçak, İslâm Hukukunda Hükümlerin Değişmesi Açısından Hz. Ömer'in Bazı Uygulamaları (Samsun: Kardeşler Ofset, 1997), 49-56; Saffet Köse, “Hz. Ömer'in Bazı Uygulamaları Bağlamında Ahkâmın Değişmesi Tartışmalarına Bir Bakış", İslâm Hukuku Araştırmaları Dergisi 7 (Nisan-2006), 15-29.

${ }^{104}$ Medkûr, Nazariyyetül-ibâha, 347; Dirînî, Muhammed Fethî, el-Hak ve medâ sultânü'd-devle fî takyîdihî, Müessesetü'r-risâle, Beyrut 1984, 112; Abdüsselam Muhammed eş-Şerif el-Âlim, Nazariyyetü's-siyaseti'ş-şer'iyye (Bingazi: Camiatü Karyûnûs, 1996), 150.

${ }^{105}$ İbnü'l-Cevzî, Menâkibü (Emîru'-Mü'minin) Ömer İbnül-Hattab, thk. Zeyneb İbrahim elKarût (Beyrut: Dâru'l-kütübi'l-ilmiyye, ty.), 79.

${ }^{106}$ Nemle, el-Mühezzeb fî̀ ilmi usûli'-fikh el-mukâren, 1/262.
} 
akıl ve tecrübesine bırakılmış bir alan tasavvuru mümkün değildir. Hal böyle olunca yakın tarihimizde cevazın şeri bir hüküm olup olmadığı yönündeki tartışmalar da kanaatimizce yersiz olacaktır." ${ }^{107}$

\section{SONUÇ}

Klasik İslam hukuku metodolojisinde / hüküm teorisinde, şer'îteklîfî hükmün tanımında yer alan "tahyîr", mükellefin muhayyer olduğu hukukî serbest alanları, yani mubah fiilleri ifade etmektedir. Bir fıkıh usulü terimi olarak mubah, herhangi bir zemm (kınama/günah) ve medh (övgü/sevap) olmaksızın Şâri'in mükellefi yapıp yapmamakta muhayyer bıraktığı hukukî serbest alanlardır.

Klasik İslâm hukuku metodolojisinde mubahın şer'î hüküm olup olmaması ile ilgili biri cumhura, diğeri Mu'tezilî âlim Ka'bî ve onun taraftarlarına ait olmak üzere iki temel yaklaşım bulunmaktadır. Cumhur, şer'î hükmün sübutunda Şâri' in hitabını esas almakta ve hitabın (nasların) tüm hayat olaylarını kuşattığını ve bu bağlamda mubahın da şer'î hüküm kapsamında yer aldığını söylemektedir. Mu'tezilî âlimler ise bir meselenin şer'î hükmünü tespit ederken Şâri'in (kanun koyucunun) o meseleye günah terettüp ettirip ettirmediğini esas almaktadırlar. Buna göre yapılmasina veya terk edilmesine her hangi bir günah terettüp etmediği için mubahın şer'î hüküm kapsamında yer almadığını söylemektedirler. Günümüz İslâm hukukçularında Vehbe ez-Zühaylî de Mu'tezilî âlimlerin bu yaklaşımını haklı bulmaktadır.

Mubahın şer'î hüküm kapsamında olup olmaması hakkında, bu derinliği olan ve tahkik etmeyi gerektiren bir mesele diyen Gazzâlî, mubah kapsamına giren fiilleri üçlü bir taksime tabi tutmuş ve bazı durumlar için Mu'tezilî âlimlerin haklı olabileceği şeklinde değerlendirmeler yapmıştır. Osmanlı'nın son dönem hukukçu düşünürlerinden Mansurizâde Said ile günümüz İslam hukukçularından Ali Bardakoğlu, Abdullah Kahraman gibi hukukçular da Mu'tezilî âlimlerin görüşüne katılmakta ve mubahın şer'î hüküm kapsamında olmamasının daha isabetli bir yaklaşım olduğunu söylemektedirler. Buna mukabil günümüz İslâm hukukçularından H. Yunus Apaydın, Mehmet Erdoğan gibi İslam hukukçuları ise nasların tüm hayat olaylarını kuşatıcılı̆̆ından hareketle mubahın da şer'î hüküm kapsamında yer aldığını, dolayısıyla cumhurun görüşünün daha isabetli olduğunu söylemektedirler.

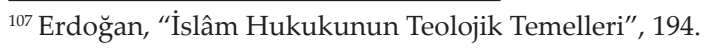


Diğer taraftan başta Mansurizâde Said ve onun görüşüne katılan bazı İslam hukukçuları mubahın şer'î hüküm olup olmaması ile devlet başkanının (kamu otoritesinin) mubahı sınırlandırma yetkisi arasında bir ilişki kurmaya çalışmışlardır. Ancak şartlara, yani vesile olduğu maslahat (menfaat) ve mefsedete (zarara) göre mubahın farklı hükümler de alabileceği dikkate alındığında, mubahın şer'î hüküm olup olmaması ile devlet başkanının (kamu otoritesinin) mubahı sınırlandırma yetkisi arasında doğrudan bir ilişki kurulmasına gerek olmadığını söylemek mümkündür. Nitekim klasik fıkıh doktrinine göre de devlet başkanının (kamu otoritesinin), şartlar ve ihtiyaçlar gerekli kıldığında, kamu yararı doğrultusunda mubahı sınırlandırma hak ve yetkisine sahip olduğu kabul edilmektedir. 


\section{KAYNAKÇA}

Âlim, Abdüsselam Muhammed eş-Şerif. Nazariyyetü's-siyaseti'ş-şer'iyye. Bingazi: Camiatü Karyûnûs, 1996.

Âmidî, Ebu'l-Hasan Ali b. Muhammed Seyfeddin. el-İhkâm fì usûli'l-ahkâm. thk. Abdurrazzak Afifi. 4 Cilt. Riyad: Dâru's-Samî̀, 2003.

Apaydın, H. Yunus. “Kurtubalı Zahiri Fakih İbn Hazm’ın Şer'î Hükümleri Tasnifi: Merâtibu'ş-Şerîa“, ISTEM: İslâm San'at, Tarih, Edebiyat ve Mûsikîsi Dergisi 7/14 (2009), 107-119.

Apaydın, H. Yunus. "Fıkıh Usulünün Temel Kabulleri ve Tarihselcilik". Din̂̂ Hükümlerin Kaynağı ve Dinî Metinlerin Anlaşılması Konusundaki Çağdaş Yaklaşımlar Çalıştayı. Ed. Cengiz Kallek. 323-364. İstanbul: İSAM Yayınları, 2010.

Apaydın, H. Yunus. “İctihad”. Türkiye Diyanet Vakfi İslâm Ansiklopedisi. 21/432-445. İstanbul: TDV Yayınları, 2000.

Apaydın, H. Yunus. Din ve Fıkıh Yazıları. Konya: Hacıveyszade İlim ve Kültür Vakfı Yayınları, 2018.

Apaydın, H. Yunus. "Siyasal Hayat”. İlmihal-II (İslam ve Toplum). 2 Cilt. 2/252-328. Ankara: Türkiye Diyanet Vakfı Yayınları, 2013.

Atar, Fahrettin. Fıkı Usûlü. İstanbul: MÜİF Yayınları, 1996.

Ayengin, Tevhit. "Hüküm Teorisi". İslâm Hukukuna Giriş. 156-184. Erzurum: Atatürk Üniversitesi Açıköğretim Fakültesi, 2011.

Bakıllânî, el-Kâdî Ebî Bekr Muhammed b. Tayyib. et-Takrîb ve'l-irşâd (es-Sağîr). thk. Abdülhamid b. Halid Ebu Zenîd. 3 Cilt. Beyrut: Müessesetü'r-Risâle, 1998.

Bardakoğlu, Ali (sadeleştiren). “Mansurizâde Saîd: Cevâzın Şer'i Ahkâmdan Olmadığına Dâir". Erciyes Ünv. Sosyal Bilimler Ens. Dergisi 1 (Kayseri 1987), 81-89.

Bardakoğlu, Ali. “Osmanlı Hukukunun Şer'îliği Üzerine”. Osmanlı (Teşkilat içinde). ed. Güler Eren. 6/412-417. Ankara: Yeni Türkiye Yayınları, 1999.

Bardakoğlu, Ali. “Fıkıh Çözüm mü Üretir, Sorun mu?”. EskiYeni: Anadolu İlahiyat Akademisi Araştırma Dergisi 29 (Güz 2014): 147-178.

Bardakoğlu, Ali. “Câiz”. Türkiye Diyanet Vakfı İslâm Ansiklopedisi. 7/27-28. İstanbul: TDV Yayınları, 1993.

Berkes, Niyazi. Türkiye'de Çă̆daşlaşma. Ankara: Bilgi Basımevi, 1973.

Beyânûnî, Muhammed Ebü'l-Feth. "Hüküm (Fıkıh)". Türkiye Diyanet Vakfı İslâm Ansiklopedisi. 28/466-468. İstanbul: TDV Yayınları, 1998.

Bihârî, Muhibbüllah b. Abdüşşekûr. Müsellemü's-sübût (Fevâtihu'r-rahamût bi şerhi Müsellemi's-sübôt ile birlikte). tsh. Abdullah Mahmud Muhammed Ömer. 2 Cilt. Beyrut: Dârul'1-kütübi'l-ilmiyye, 2002.

Bilmen, Ömer Nasuhi. Hukuk-ı İslâmiyye ve Istılahât-ı Fıkhiyye Kâmûsu. 8 Cilt. İstanbul: Bilmen Yayınları, 1985. 
Biltâcî, Muhammed. Menhecü Ömer İbnül-Hattâb fi't-teşrî: Dirâse müstev'ıbe li fikhi Ömer ve tanzîmihî. Kahire: Dâru'l-fikri'l-Arabî, 1970.

Birinci Ali ve M. Sait Özervarlı, “İzmirli, İsmail Hakkı”. Türkiye Diyanet Vakfı İslâm Ansiklopedisi. 23/530-535. İstanbul: TDV Yayınları, 2001.

Cessâs, Ebu Bekir Ahmet b. Ali er-Râzî. Ahkâmü'l-Kur'ân. thk. Muhammed Sadik Kamhâvî. 5 Cilt. Beyrut: Dâru ihyâi't-türâsi'l-Arabî, 1985.

Cessâs, Ebu Bekir Ahmet b. Ali er-Râzî. el-Fusûl fill-usûl. thk. Uceyl Casim enNemşi. 4 Cilt. Kuveyt: 1994.

Cürcânî, Ebü'l-Hasan Seyyid Şerif Ali b. Muhammed b. Ali. et-Ta'rifât. Beyrut: Dârü'l-Kütübi'l-İlmiyye, 1983.

Cüveynî, İmamü'l-Harameyn Ebu'l-Meâlî Abdullah b. Abdullah Yusuf. el-Burhân fî usûli'l-fikh. thk. Abdulazim Muhammed ed-Dîb. 2 Cilt. Katar: b.y., 1399/1979.

Çakan, İsmail Lütfi. “Babanzade Ahmet Naim”. Türkiye Diyanet Vakfı İslâm Ansiklopedisi. 4/375-376. İstanbul: TDV Yayınları, 1991.

Dirînî, Muhammed Fethî. el-Hak ve medâ sultânü'd-devle fî̀ takyîdihî. Beyrut: Müessesetü'r-risâle, 1984.

Dirînî, Muhammed Fethî. Hasâisü't-teşrîill-islâmî fi's-siyaseti ve'l-hükm. Beyrut: Müessesetü'r-risâle, 2013.

Dönmez, İbrahim Kâfi, "Mubah", Türkiye Diyanet Vakfı İslâm Ansiklopedisi. 30/341345. İstanbul: TDV Yayınları, 2005.

Dumlu, Emrullah. "Hukukî Serbest Alan: Mubah (Klasik Yaklaşım ve Şâtıbî Örneği)". İslâm Hukuku Araştırmaları Dergisi 22 (Ekim 2013), 157-186.

Ebû Zehra, Muhammed. Usûlül-fikh. İstanbul: Tebliğ Yayınları, ts.

Ebû Zehra, Muhammed. el-Cerîme. Kahire: Dâru'l-fikri'l-Arabî, 1986.

el-Mevsûatü'l-Fıkhiyye. "İbâha”, Vizâratü'l-evkâf ve'ş-şuûni'l-islâmiyye. 1/132135. Kuveyt: 1983.

Ensârî, Ebû Ayyâş Muhammed Abdül'alî b. Nizamüddin Bahrululûm el-Leknevî. Fevâtihu'r-rahamût bi şerhi Müsellemi's-sübût. tsh. Abdullah Mahmud Muhammed Ömer. 2 Cilt. Beyrut: Dârul'1-kütübi'l-ilmiyye, 2002.

Erdoğan, Mehmet. Fıkıh ve Hukuk Terimleri Sözlüğü. İstanbul: Rağbet Yayınları, 1998.

Erdoğan, Mehmet. "İslâm Hukukunda Şer'îlik Kavramı". İslâmî Araştırmalar Dergisi 19/1 (2006), 145-151.

Erdoğan, Mehmet. "İslâm Hukukunun Teolojik Temelleri”. İslâm Fıkhını Nasıl Anlamalıyız (Sempozyum Tebliğ ve Müzakereleri). 189-195. Bursa: KURAV Yayınları 2006.

Gazzâlî, Ebû Hâmid Muhammed. el-Müstasfâ min ilmi'l-usûl. thk. Hamza b. Züheyr Hafız. 4 Cilt. Medine: b.y., ts.

Hâdimî, Ebu Saîd. Mecâmiu'l-hakâik. nşr. Şirketü Sahafiyye Osmaniyye müdürü elHâc Ahmed Hulûsî. İstanbul: Matbaa-i Âmire, 1308/1891. 
Halîmî, Ebû Abdillah el-Huseyin b. Hasen. el-Minhâc fî şuabil-îmân. thk. Halîmî Muhammed Kûde. 3 Cilt. Beyrut: Daru'l-fikr, 1979.

Hallâf, Abdülvahhab. İlmü usûli'l-fikh. İstanbul: el-Mektebetü'l-İslâmiyye, 1984.

Husarî, Ahmed. Nazariyyetül-hükm ve mesâdirü't-teşrî fì usûli'l-fikhil-İslâmî. Beyrut: Dârü'l-Kitâbi'l-Arabi, 1986.

İbn Abdüsselâm, İzzeddin (İzz), Ebu Muhammed es-Sülemî. Kavâidül-ahkâm fi mesâlihil-enâm. thk. Nezih Kemal Hammad ve Osman Cuma Damiriyye. 2 Cilt. Dımeşk: Dâru'1-Kalem, 2000.

İbn Âbidîn, Muhammed Emin. Reddü'l-muhtâr ale'd-Dürril-muhtâr şerhu Tenvîri'lebsâr. thk. Adil Ahmed Abdülmevcud - Ali Muhammed Muavvad. 13 Cilt. Dâru Alemi'l-kütüb, 2003.

İbn Hazm, Ebu Muhammed Ali b. Ahmed b. Saîd. el-i̇hkâm fî usûlil-ahkâm. thk. Muhammed Şakir. 8 Cilt. Beyrut: Dâru'l-âfâki'l-cedîde, ts.

İbn Kayyim, et-Turuku'l-hükmiyye fi's-siyaseti'ş-er'iyye. thk. Nayif b. Ahmed elHamed. 2 Cilt. Mekketü'1-Mülerrame: Dâru Âlemi'l-fevaid, 1428/2007.

İbn Kayyim. Î'lâmü'l-muvakkı̂nn an rabbi'l-âlemîn. 7 Cilt. Riyad: Dâru İbnül Cevziyye, $1423 / 2002$.

İbn Manzûr, Ebu'1-Fazl Cemalüddin. Lisânü'l-Arab. 6 Cilt. Kahire Dâru'l-meârif, 1984.

İbnü'l-Cevzî, Ebil Ferac Cemalüddin Abdurrahman b. Ali. Menâkibü (Emîru'lMü'minin) Ömer İbnül-Hattab. thk. Zeyneb İbrahim el-Karût. Beyrut: Dâru'1kütübi'l-ilmiyye, ts.

İltaş, Davut. Fıkıh Usulünde Mütekellimîn Yönteminin Delâlet Anlayışı. İstanbul: İSAM, 2011.

İzmirli, İsmail Hakkı. “Cevâzın Ahkâm-ı Şeriattan Olup Olmaması Hakkındaki Nizâ' Nizâ-i Lafzîdir". Sebilü'r-Reşad [Strat-ı Müstakim] 12/303 (19 (Haziran 1330/1912), 296-301.

İzmirli, İsmail Hakkı. “Cevazın Ahkâm-1 Şeriattan Olup Olmadığ1-2”. Sebilü'rReşad [Strat-ı Müstakim] 12/304 (Haziran 1330/1912), 315-319.

Kahraman, Abdullah, (Yayına Haz.). "Şeriat ve Kânûn (Mansurizâde Mehmed Saîd)". İslâmiyât, (Şeriat Dosyası) 1/4 (Ekim-Aralık 1998), 239-251.

Kahraman, Abdullah. "Daru'l-Fünûn Hocalarından Mansûrizâde Mehmed Saîd Ve Klasik Fıkhın Sınırlarını Zorlayan Bazı Görüşleri”. Daru'-Fünûn İlahiya Sempozyumu Tebliğleri. 405-414. İstanbul: 2010.

Kahraman, Abdullah. "Mansurizâde Saîd'in Klasik Fıkıhçlara Yönelttiği Bazı Eleştiriler". Cumhuriyet Üniversitesi İlahiyat Fakültesi Dergisi 5/1 (Sivas 2001), 233-247.

Kallek, Cengiz. "Müellefe-i Kulûb". Türkiye Diyanet Vakfı İslâm Ansiklopedisi. 31/475476. İstanbul: TDV Yayınları, 2006.

Kara, İsmail. Türkiye'de İslâmcılık Düşüncesi. 2 Cilt. İstanbul: Risale Yayınları, 1987. 
Karâfî, Şihabüddin Ebu'l-Abbâs Ahmed b. İdris es-Sanhâcî. el-Furûk fi Envâri'lburûk fi envâi'l-furuk. 4 Cilt. Beyrut: Dâru'l-kütübi'l-ilmiyye, 1998.

Karâfî, Şihabüddin Ebu'l-Abbâs Ahmed b. İdris es-Sanhâcî. Şerhu tenkîhu'l-fusûl fi ihtisâri'l-Mahsûli fi'l-usûl. Beyrut: Dâru'l-fikr, 2004.

Karatepe, Tuba Çavdar. “İslâm Mecmuası”. Türkiye Diyanet Vakfi İslâm Ansiklopedisi. 23/53-54. İstanbul: TDV Yayınları 2001.

Kâsânî, Ebû Bekr Alâaddin b. Mes'ûd. Bedâiu's-sanâi' fî tertîbi'ş-şerâi'. thk. Ali Muhammed M uavvad. 10 Cilt. Beyrut: Dâru'l-kütübi'l-ilmiye, 2003.

Koç, Ekrem. İslâm Hukuk İlminde Cevaz Kavramı. İstanbul: Marmara Üniversitesi, Sosyal Bilimler Enstitüsü, Yüksek Lisans Tezi, 2008.

Koçak, Muhsin. İslâm Hukukunda Hükümlerin Değişmesi Açısından Hz. Ömer'in Bazı Uygulamaları. Samsun: Kardeşler Ofset, 1997.

Köse, Saffet. “Hz. Ömer'in Bazı Uygulamaları Bağlamında Ahkâmın Değişmesi Tartışmalarına Bir Bakış". İslâm Hukuku Araştırmaları Dergisi 7 (Nisan-2006), 13-50.

Kurtubî, Ebû Abdillah Muhammed b. Ahmed el-Ensârî. el-Câmi li ahkâmi'l-Kur'ân. thk. Abdullah b. Abdulmuhsin et-Türkî. 24 Cilt. Beyrut: Müessesetü'rrisâle, 2006.

Mansurizâde Saîd. "Cevazın Ahkâm-ı Şer'iyyeden Olmadığına Dâir". İslâm Mecmuası 1/10. (İstanbul 1330), 295-303.

Mansurizâde Saîd. "Şeriat ve Kanun-I". Daru'l-Funun Hukuk Fakültesi Mecmuası (DFHM) 1/6 (1332-1334), 530-535.

Mansurizâde Saîd. "Şeriat ve Kanun-II". Daru'-Funun Hukuk Fakültesi Mecmuası (DFHM) 2/8 (1332-1334), 601-606.

Mansurizâde Saîd. “Taaddüd-i Zevcât İslâmiyette Men Olunabilir". İslâm Mecmuast 1/8 (1330/1912), 233-238.

Medenî, Muhammed Muhammed. Nazarât fî fikhi'l-Farûk Ömer ibni'l-Hattâb. Kahire: b.y., 2002.

Medkûr, M. Sellâm. Nazariyyetu'l-ibâha inde'l-usuliyyin ve'l-fukâhâ. Kahire: Dâru'nNehdati'l-Arabiyye, 1984.

Medkûr, M. Sellâm. Mebâhisü'l-hükm inde'l-usûliyyîn. 2 Cilt. Kahire: Dâru'nnehdati'l-arabiyye, 1959.

Molla Hüsrev. Mir'âtü'l-usûl. İstanbul: Dersaâdet, 1321/1904.

Nemle, Abdülkerim b. Ali b. Muhammed. el-Mühezzeb fì ilmi usûli'l-fikh el-mukâren. 4 Cilt. Riyad Mektebetü'r-rüşd, 1999.

Râzî, Fahreddin. el-Mahsûl fi ilmi'l-usûl. thk. Cabir Feyyyâd el-Alvânî. 6 Cilt. Beyrut: Müessesetü'r-Risâle, ts.

Serahsî, Ebû Bekr Muhammed b. Ebî Sehl. Usûlül-s-Serahsî. thk. Ebu'l-vefa elAfğanî. 2 Cilt. Beyrut: Dâru'l-Ktübi'l-ilmiyye, 1993.

Serahsî, Ebû Bekr Muhammed b. Ebî Sehl. el-Mebsût. 31 Cilt. Beyrut Dâru'1-ma'rife, 1989. 
Seyyid Bey, Muhammed. Fıkıh Usulü (Giriş). Yay. Haz: Hasan Karayiğit. İstanbul: Düşün Yayınları, 2010.

Şaban, Zekiyyüddin. İslâm Hukuk İlminin Esasları (Usûlül-fikıh). çev. İbrahim Kâfi Dönmez. Ankara: Türkiye Diyanet Vakfı Yayınları 2015.

Şâfiî, Muhammed b. İdris. er-Risâle. thk. Ahmed Muhammed Şakir. Beyrut: Daru'lkütübi'l-ilmiyye, ts.

Şâtıbî, Ebû İshak İbrahim b. Mûsâ. el-Muvâfakât fî usûli'ş-şeriâ. nşr./thk. Abdullah Diraz. 4 Cilt. Beyrut: Dâru'l-marife, 1975.

Şevkânî, Muhammed b. Ali b. Muhammed. İrşâdül-fühûl ilâ tahkîki ilmi'l-usûl. thk. Ebu Mus'ab Muhammed Saîd el-Bedrî. Beyrût: Müessesetü'l-kütübi'ssikâfiyye, 1992.

Teftazânî, Sa'duddin Mes'ûd b. Ömer. Şerhu't-Telvîh ala't-Tavdîh li metni't-Tenkîh fî usulil-fikh. 2 Cilt. Beyrut: Dâru'l-kütübi'l-ilmiyye, Birinci baskı, ts.

Türcan, Talip. “Sünnî ve Mu’tezilî Fıkı Usulünün Tanımlanmasında Bir Kriter Olarak Şer'îlik Algısı ve İbâha Alanının Şer'îliği Sorunu Bağlamında Bir Örnekleme". Marife Bilimsel Birikim 3 (2005), 195-211.

Yılmaz, Ayşegül. Mansurizâde Saîd ve Fıkhî Görüşleri. İstanbul: Marmara Üniversiten si, Sosyal Bilimler Enstitüsü, Yüksek Lisans Tezi, 2003.

Zerkâ, Mustafa Ahmed. el-Medhalül-fikhiyyü'l-âmm/el-Fıkhu'-İslâmî fi sevbihi'l-cedîd. 3 Cilt. Dimeşk: Dâru'l-Fikr, 1968.

Zerkeşî, Ebû Abdillah Bedruddin Muhammed b. Bahadır eş-Şâfiî. el-Bahru'-muhît fì usûlil-fikh. nşr. Abdulkadir Abdullah el-Ânî - Ömer Süleyman el-Aşkar. 6 Cilt. Kuveyt: Vizâratü'l-evkâfi'ş-şuûniyye, 1992.

Zeydan, Abdülkerim. el-Vecîz fì usîli'-fikh. Beyrut: Müessesetü'r-Risâle, 2011.

Zühaylî, Vehbe. Usulü'l-fikhi'l-islâmî. 2 Cilt. Dimeşk: Dâru'l-fikr, 1986. 